Linköping Studies in Science and Technology

Thesis No. 1677

\title{
Lean in the Public Sector \\ Possibilities and Limitations
}

\author{
Erik Drotz
}

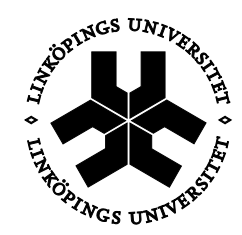

\section{Linköping University}

Department of Management and Engineering

Linköping University, Sweden

Linköping 2014 
Lean in the Public Sector -

Possibilities \& Limitations

(C) Erik Drotz, 2014

Published article has been reprinted with the permission of the copyright holder.

Printed in Sweden by LiU-Tryck, Linköping, Sweden, 2014

ISBN: 978-91-7519-229-1

ISSN: 0280-7971 


\section{Abstract}

The demands on efficiency and quality in the public sector have increased over the past few years, which have raised the need for strategies on how the public sector can be improved (Denhardt and Denhardt, 2000). Consequently, the concept of Lean production, or just Lean, have become increasingly spread, especially in health care, but also in government agencies, police, military and social services. Lean production is an integrated operational and socio-technical system with the aim of creating value and reducing waste in operations. Some research has been conducted on Lean in the public sector, but it has been too focused on the a few operational tools and results of these, and there is lack of a comprehensive critical review of Lean from a holistic perspective.

The aim of this thesis is to increase understanding of how Lean production is used in different contexts. The thesis particularly focuses on the public sector, and investigates the possibilities and limitations of Lean production in this context. A total of seven organizations have been studied, including two manufacturing companies, three care units and two local businesses. In particular, qualitative methods have been used, along with some quantitative.

The thesis shows several possibilities and limitations of Lean in public sector. One possibility is the improved flow orientation that reduces the lead time and efficiency in back office processes. Moreover, the new roles and responsibilities can lead to improved job characteristics for public sector employees. One limitation is that Lean is more commonly used to improve the technical quality than the functional, which means that the focus has been placed on improving the instrumental performance of the service, rather than how the service is provided. There is also often a focus on efficiency in the back office rather than the front office processes. This means that Lean initiatives may become too focused on internal efficiency and thereby miss important aspects of user perceived quality. 


\section{Sammanfattning}

Kraven på effektivitet och kvalitet inom offentlig sektor har aktualiserats under de senaste åren, vilket har ökat behovet av strategier för hur offentlig verksamhet kan förbättras (Denhardt and Denhardt, 2000). Som ett led i detta har konceptet Lean Production, eller bara Lean, fått en allt större spridning, framförallt inom hälsooch sjukvård, men även inom statliga myndigheter, polisväsen, militär och socialtjänst. Lean Production är ett integrerat operationellt och sociotekniskt system med syfte att skapa värde och minska slöseri i verksamheter. Det har utförts en del forskning om Lean i offentlig sektor, men den har varit allt för inriktad på enskilda operationella verktyg och resultat av dessa och det saknas en övergripande kritisk granskning av Lean ur ett helhetsperspektiv.

Syftet med avhandlingen är att öka förståelsen om hur Lean används i praktiken och vilka möjligheter och begränsningar som det har inom offentlig sektor. Totalt sju organisationer har studerats, varav två tillverkningsföretag, 3 vårdenheter och 2 kommunala verksamheter. Framförallt har kvalitativa metoder använts, men även inslag av kvantitativa.

Avhandlingen visar flera möjligheter och begränsningar med Lean inom offentlig sektor. En möjlighet är ett förbättrat flöde, som minskar ledtider och effektivitet $i$ backoffice processer. Dessutom kan nya roller och ansvarsområden leda till förbättrade jobbegenskaper för anställda $\mathrm{i}$ offentligt sektor. En begränsning är att Lean är oftare används för att förbättra den tekniska kvalitet än den funktionella, vilket innebär att fokus har lagts på att förbättra den instrumentella prestandan av tjänsterna, snarare än hur de utförs. Det är ofta ett fokus på effektivitet $i$ backoffice i stället för frontoffice processer. Det innebär att Lean initiativ kan bli alltför fokuserade på intern effektivitet och därmed missa viktiga aspekter av användarens upplevda kvalitet. 


\section{Acknowledgements}

There are many people I would like to thank for supporting me in the process of writing this thesis. First of all, my supervisor Bozena Poksinska, who has been committed and patient when giving me advice about the thesis. For that I am truly grateful. I also want to thank Jon Engström for constructive feedback and very good suggestions for improvement on the manuscript, and Jostein Langstrand for the cooperation with Paper I.

I have had the pleasure to work in an inspiring environment and I want to thank the rest of the division of Quality Management and Technology: Mattias, Peter, Hannah, Promporn, Elisabeth, Lilian, Martina and Margo for cooperation and social working life.

The collection of data would not have been possible without cooperation from external organizations and I want to thank all the organizations that have given of their time and commitment to this research project. I want to say a special thanks to Carolin Meijer-Larsson for giving me the opportunity to conduct research on the Lean implementation at the social service office in Linköping.

I also want to thank my family and friends for encouragement and support in many ways.

Last but not least, I want to thank my wife Sofie. You are the most important person in my life, and your help, encouragement and love gives me comfort, hope and joy every day. I love you! 


\section{Appended papers}

I. Langstrand, J., Drotz, E., (2014) The Rhetoric and Reality of Lean Working paper

The author of this thesis contributed to research idea, research design, empirical work, analysis and writing

2. Drotz, E., Poksinska, B., (20l4) Lean in healthcare from the employee perspective

Published in Journal of Health Organization and Management, Vol. 28 Iss: 2, Pp. 177 - 195

The author of this thesis contributed to research idea, research design, empirical work, analysis and writing

3. Drotz, E., Poksinska, B., (2014) Possibilities and Limitations of Lean in Social Service

Presented on QMOD Conference, $3^{\text {rd }}-5^{\text {th }}$ September, 2014, Prague, Czech Republic

The author of this thesis contributed to research idea, research design, empirical work, analysis and writing 


\section{Contents}

Abstract ................................................................................................................. ii

Sammanfattning .............................................................................................................ii

Acknowledgements ........................................................................................................... iv

Appended papers ..........................................................................................................

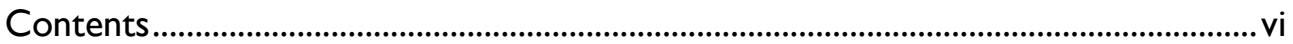

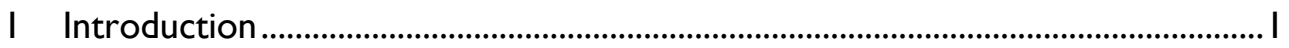

I.I Outline of the thesis ........................................................................................

2 Theoretical framework............................................................................................

2.1 Lean Production........................................................................................

2.I.I Define customer value...................................................................................

2.1.2 Define value stream .......................................................................................

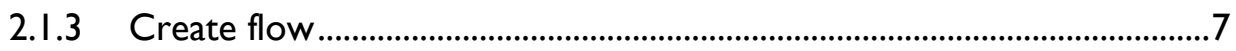

2.I.4 Establish pull ..............................................................................................8

2.1.5 Strive for perfection ..............................................................................

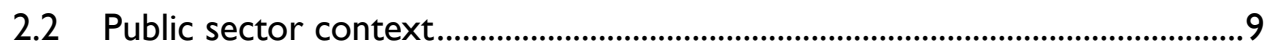

2.2.1 Customer in public sector .............................................................................

2.2.2 Quality in public sector ......................................................................... 10

2.2.3 Processes in public sector ....................................................................... 10

2.3 Lean Service ................................................................................................... I

2.4 Lean in public sector ............................................................................. 13

3 Methodology ................................................................................................... 17

3.I Research Overview................................................................................... 17

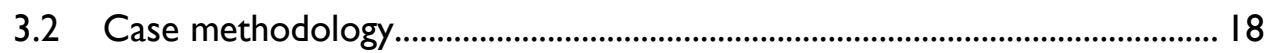

3.2.1 Description of cases................................................................................ 19 


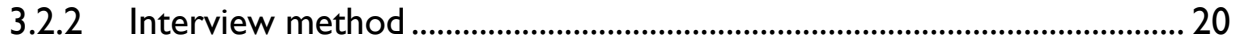

3.2.3 Document studies ..................................................................................... 24

3.2.4 Participative observations ......................................................................... 24

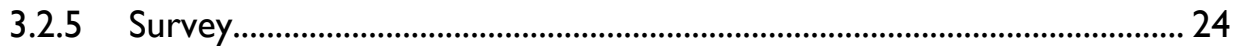

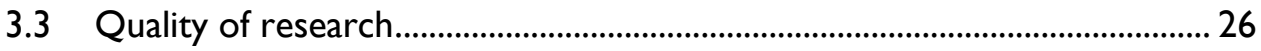

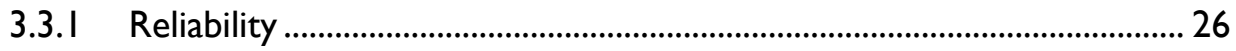

3.3.2 Construct validity ..................................................................................... 26

3.3.3 Internal validity..................................................................................... 27

3.3.4 External validity...................................................................................... 27

4 Summary of appended papers ............................................................................ 29

4.I Paper I - The rhetoric and reality of Lean production................................... 29

4.I.I Lean in rhetoric and in practice.................................................................. 29

4.2 Paper 2 - Lean in healthcare from the employees' perspective ................... 35

4.2.I Change in roles, responsibilities and job characteristics ......................... 37

4.2.2 Main conclusions...................................................................................... 38

4.3 Paper 3 - Possibilities and limitations of Lean in social service .................... 39

4.3.I Possibilities and limitations ……………………………………………...... 39

5 Discussion ......................................................................................................

5.I RQI: How is Lean production used in practice? ......................................... 4 I

5.2 RQ2: Which Lean principles, methods and tools are used in the public

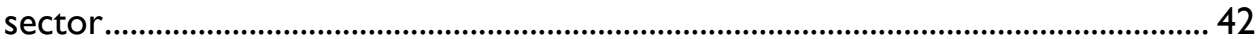

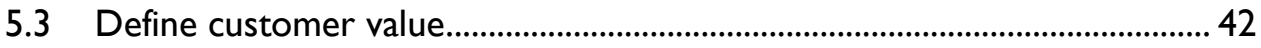

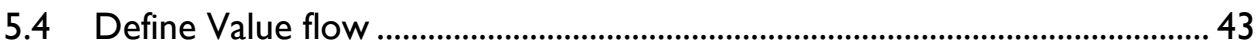

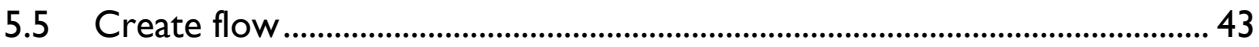

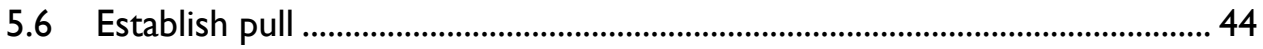

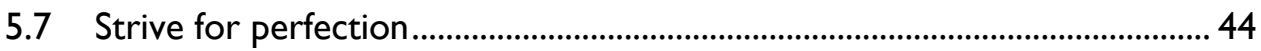


5.8 RQ3: What are the possibilities and limitations of using Lean in the public sector 46

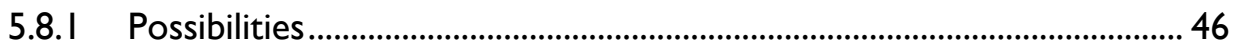

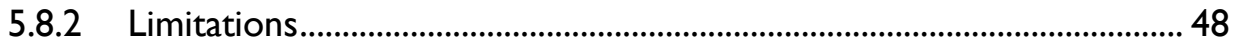

6 Conclusion and contribution............................................................................ 5 I

6.I Theoretical implications .............................................................................. 5 I

6.2 Managerial implications................................................................................ 54

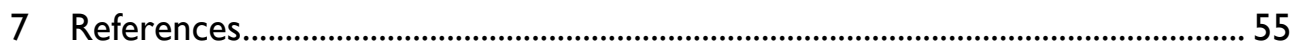

Figure I: Main ideas of the Toyota Way (Toyota Way 200I, 2014) ..........................5

Figure 2: Five principles of Lean.....................................................................................

Table I: Overview of research design.................................................................... 17

Table 2: Overview of cases and methodology............................................................ 18

Table 3: Interviews performed at case organizations.................................................... 22

Table 4: Summary of cases............................................................................................ 30

Table 5:Core job characteristics in Lean manufacturing (based on Treville and

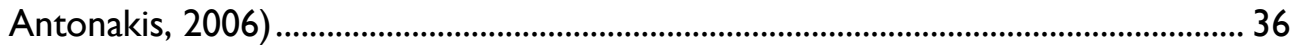

Table 6: Possibilities and limitations............................................................................. 46

Table 7: A model for improving quality in public service organizations .................... 52 



\section{Introduction}

Both Alison and Sarah had the same need: They wanted to find out if they had cancer. They both went through various tests and were given diagnosis. The similarities end there.

From Alison's first visit to her local doctor to the moment she received her diagnosis, forty-two days elapsed, which is equivalent to 1008 hours. In Sarah's case, it only took two hours between her first contact with the nurse at this one-stop breast clinic until she received her diagnosis. Sarah's diagnosis process was more than five-hundred times faster than Alison's. Is that a big difference? It is an enormous difference.

Modig and Åhlström (20ll) tell a story about two women with the same needs and preconditions. Whereas Alison went into the traditional healthcare process with independently managed functions, Sarah went to a one-stop breast clinic, built on Lean production principles. In this case, the aim was to reduce the waiting time between subsequent process steps as much as possible. Although the actual care (the work by doctors, nurses, and biomedical analysts) did not change dramatically, the time from detection of a symptom to diagnosis was radically shorter for Sarah.

From being developed in the automobile industry, the use of Lean production spread to many industrial and service contexts. Increased competition and globalization has raised a need for lower costs and higher quality in producing goods and services, which generally explains the success of Lean as a concept (Hines et al., 2004; Souza, 2009). However, what is Lean, and how did it become the most used concept for developing organizations in the Western world? Lean originates from the Toyota Production System and was an attempt to explain the philosophies and practices that made Toyota so successful compared to American and European competitors. The Toyota Production System consists of two major ideas: Respect for people and continuous improvement (Toyota Way 200I). The former idea means to develop employees, leaders and suppliers, while the latter is related to production processes and how to improve them. In this respect, Lean should be viewed as a system, and developing processes is strongly related to developing people (Liker, 2004). 
However, there is no consensus of what it means to work with Lean (Pettersen, 2009). The typical way to use it is as a process improvement approach with a focus on the reduction of waste (Liker, 2004). Consequently, most cases have a limited scope and use only a few shop-floor tools and techniques in limited parts of the organization (Bhasin and Burcher, 2006). There is often a lack of strategic connection and customer focus when Lean is used (Liker and Hoseus, 2010). However, as in all management concepts, there is a need for translating, rather than copying, Lean into different contexts (Benders and Slomp, 2009). Lillrank (1995) has suggested a model for the translation of management concepts between Japanese and Western cultures, which also can be used for translation between different sectors. The model suggests that the management concept should go through a process consisting of abstraction, meaning that the essential models, tools, propositions of casual connections and illustrative examples are packaged and transferred to and applied in the new context (ibid). In this thesis, the public sector is of particular interest, which has its own culture (Parker and Bradley, 2000), traditions (Bevir et al., 2003), and management paradigms (Lane, 2000).

Lean as a way to improve the public sector has increased dramatically during recent years, primarily in healthcare, but increasingly in other public organizations and authorities. In Sweden, 90 percent of the hospitals use Lean to at least some extent (Högfelt et al., 20II). It is also used in other parts of the public sector such as police (Orre and Kirsebom, 20II), schools (Jansson and Sorpola, 2012), and public authorities (Brandt and Stigendahl, 20I2). The concept is also common in Denmark (Pedersen and Huniche, 20I I), Great Britain (Radnor and Osborne, 2013), the United States (Souza, 2009), and many other countries in the Western world. The one-stop breast clinic is an example of a success story that is often used to motivate using Lean in the public sector. However, although there is certainly experience that is useful in such cases, they do not problematize limitations Lean production has in the public sector. Instead, they focus on specific tools, methods, and outcomes for the organization (Radnor and Osborne, 2013). Reducing lead time is often emphasized in Lean implementations within the public sector, which is further highlighted by the quote from Lord (Sonne, 2009 p.6), responsible for the Lean work at Skåne University Hospital: 
The results were positive enough to continue the work: ADHD team managed to reduce investigation time from 4 months to 3 weeks and increased their capacity by $70 \%$. Average time from door to door in the emergency department for patients with suspected fracture was halved, and for cervical cancer, where four different centers were involved, reduced investigation time from four weeks to 9 days.

Regarding the origin of Lean in automotive manufacturing, it is no surprise that the use of Lean in other contexts is debated and questioned, and the public sector is no exception. One criticism is that Lean focuses too much on internal efficiency and production metrics so is only an improvement for internal efficiency not for the patient (Bertholds, 2010; Radnor, 2010b; Zaremba, 2013). Other writers agree that Lean often has the wrong focus when it is implemented in healthcare, but suggest that this depends on the interpretation of the concept rather than the concept itself (Modig and Åhlström, 2013). Several researchers stress that most of the barriers toward Lean implementation in public sector are related to resistance from people, leadership failures, identity of improvement team members, weak links between improvement programs and strategy, lack of resources, poor communication, and functional and professional silos (de Souza and Pidd, 20I I; Radnor et al., 2006). Considering the lack of knowledge about the relevance of Lean in the public sector, there is a need for a deeper investigation on how Lean is used in the public sector and how it fits in that context. In order to do this, a discussion about the current paradigm and future challenges in public management is needed. Therefore, there is a need to go deeper into the content and context of change when it comes to Lean. In this thesis, Lean in the public sector is further explored, especially the interconnection between content and context.

This leads us to the aim of this thesis. The aim of the thesis is to increase understanding of how Lean production is used in practice different organizations. This thesis particularly focuses on the public sector, and investigates the possibilities and limitations of Lean production in this context. 
In order to fulfill this aim, the following research questions will be addressed.

RQI: How is Lean production used in practice?

RQ2: Which Lean principles, methods, and tools are used in the public sector?

RQ3: What are the possibilities and limitations of using Lean in the public sector?

\section{I.I Outline of the thesis}

The three papers included in this thesis provide different perspectives on this matter. Paper $I$ is a cross case study of how Lean is used in manufacturing, healthcare, and municipal services. This paper is a basis for the discussion of Research Question I. The two other papers provide different perspectives on Lean in public sector, which is a basis for answering Research Questions 2 and 3. Paper 2 is built on Lean implementations in three healthcare organizations and explores the roles, responsibilities, and job characteristics in public organizations working with Lean. The main purpose with Paper 3 is to explore how Lean is used in a social service context, and the possibilities and limitations for the organization. This is done by a single case study on the Lean implementation in a social service organization. The three papers can be found in the appendix.

This thesis uses the following structure: Chapter I consists of background and motivation for the research area, leading to the aim and the research questions that will be addressed, as well as the structure of this thesis. Chapter 2 presents the theoretical perspective that this thesis is based on and that relates to the research questions presented in the introduction. Chapter 3 presents and discusses the methodological approach in terms of research quality. Chapter 4 summarizes the appended papers and presents a short background, aim, main findings, and conclusions. Chapter 5 consists of an analysis and a discussion related to the research questions, based on the contributions from the appended papers. Finally, Chapter 6 discusses the theoretical and practical implications of this thesis, as well as suggestions for further research. 


\section{Theoretical framework}

This chapter contains perspectives from research field that relate to the topic of this thesis. It presents the following theories and models: An introduction of the concept of Lean and how it is used in the public sector context; a review of the contextual characteristics of the public sector regarding customer, quality and process; and finally an overview of the research that has been carried out about Lean in service in general and in public sector in particular.

\section{I Lean Production}

Lean production was originally a conceptualization of the Toyota Production System (TPS), made in the International Motor Vehicle Program at MIT, and was popularized by The Machine that Changed the World (Womack et al., 1990). Earlier on, research about TPS consisted of descriptions on specific tools and techniques, such as Just-in-Time (JIT) and Kanban (Monden, 1983; Schonberger, 1982; Schroer et al., 1985; Sugimori et al., 1977), Jidoka (Monden, 1983; Ohno, 1988; Pegels, 1984; Sugimori et al., 1977), and Single-Minute Exchange of Dies (SMED) (Shingo and Dillon, 1989), but none of them considered the whole management system at Toyota (Holweg, 2007). Therefore, Womack et al. (1990) set a starting point for viewing Lean as a concept, and the research has continued to develop the knowledge of the principles and practices behind Toyota's success. In 200I, Toyota documented the guiding values of their management system, respect for people and continuous improvement, each of which is associated with certain principles, seen in Figure I (Toyota Way 200 I, 20I4).

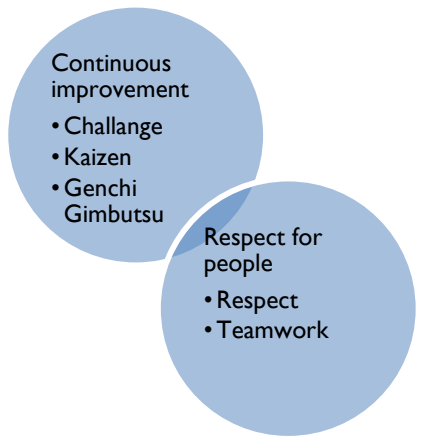

Figure I: Main ideas of the Toyota Way (Toyota Way 200I, 2014) 
Respect for people comprises respect for individuals and their differences, as well as the personal and professional growth of the employees as team members, while continuous improvement labels the idea of always strive for improvements to reduce waste and increase value for the customer (Liker, 2004). Therefore, one basic theme in Lean is to always challenge the existing way of working, which will generate ideas for improvements. Kaizen means improvement in Japanese and is commonly used to describe continuous improvement work built on employee participation. Genchi Gimbutsu (Go-andsee) represents a leadership practice in which the manager always gets information by going out on the factory floor and making decisions based on this information. By describing Lean as continuous improvement and respect for people, the social aspects of Lean were emphasized. In combination with the tools and techniques that were described in the earlier publications, Lean became a sociotechnical system, consisting of both a social and a technical system. This has been further developed and described by several authors (Dahlgaard and Dahlgaard-Park, 2006; Liker, 2004; Shah and Ward, 2007).

From being rather overlooked in Western literature, interest in employees' roles in Lean organizations has increased during recent years (Joosten et al., 2009). This is partly as a response to the critique against Lean from a work environment perspective. Several authors claim that Lean will lead to increased stress and reduced potential for creativity and innovation (Landsbergis et al., 1999; Parker, 2003). However, respect for people was described as a key principle as early as 1977 (Sugimori et al., 1977), which included developing workers' capabilities by reducing wasteful movement, considering their safety and entrusting them with greater responsibility and authority. It is foremost the increased responsibility and authority that is currently discussed in Western literature. Involving employees in a continuous improvement work has become an important part of a modern interpretation of Lean (Joosten et al., 2009; Liker, 2004).

Figure 2 represents a well-known model for describing Lean is the five principles developed by Womack and Jones (1996) 
Define

customer

value

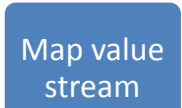

stream
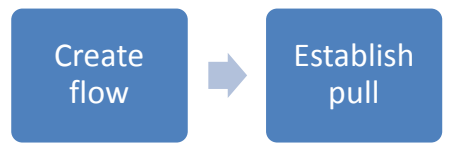

Strive for

perfection

Figure 2: Five principles of Lean

\section{I.I Define customer value}

A stronger customer perspective is commonly a principal aim of Lean production (Hines et al., 2004; Liker and Meier, 2006; Womack and Jones, 1996). Therefore, the first principle, as defined by Womack and Jones (1996), is defining the value from the customer's perspective, meaning specifying requirements of the product or service. In order to increase the value, both reducing wasteful activities and adding features that do add value to the product or service can be done (Hines et al., 2004). Womack and Jones (1996) emphasize that the value only can be defined by the ultimate customer, rather than by employees or managers within the company.

\subsubsection{Define value stream}

The customer value serves as a basis for defining the value stream, which means mapping and analyzing the activities in the process and how they add value to the product. The aim of using value stream mapping is to identify waste in value streams to find appropriate tools to remove it (Hines and Rich, 1997). Within the value stream, there are three types of activities: Activities that add value to the product or service; activities that do not add value but are necessary for the value-adding activities; and activities that do not create value for the end customer (Womack and Jones, 1996). The two latter types of activities are defined as waste, but only the third type should be removed instantly (ibid). Mapping and analyzing the value stream is often the first method when starting Lean work in public-sector organizations (Poksinska, 2010).

\subsubsection{Create flow}

To create continuous flow means to let products flow through the process rather than producing in batches that are moved between process steps (Womack and Jones, 1996), with no idling time between work activities (Liker 
and Meier, 2006). By creating a continuous flow, waste can be reduced in the process. The seven types of waste defined by Toyota are: Overproduction, waiting time for workers, transportation of goods, overprocessing or incorrect processing, excess inventory, unnecessary movement, and defects (Liker and Meier, 2006). In order to achieve a flow-based production, the boundaries between functions, departments, and professional groups must be decreased (Ohno, 1988; Womack and Jones, 1996), as well as increasing stability in the process. An important principle in Lean is the leveled production, both with respect to the total production rate but also to the order mix (Monden, 1983). One tool for acquiring this is visual control, which is a way of making the process transparent to prevent overproducing and better take care of unexpected interruptions such as absence due to illness (Womack and Jones, 1996).

\section{I.4 Establish pull}

Pull means that goods or services only are produced when the internal or external customer needs it (Womack and Jones, 1996). Liker (2006) defines three elements that distinguish pull from push: The product volume, model mix, and sequence are defined between supplier and (internal or external) customer. Items such as resources, locations, and storages are shared between customer and supplier. A simple control method, preferably visible, regulates the connection between supplier and customer. Kanban is a common method to achieve this (Monden, 1983; Ohno, 1988; Sugimori et al., 1977).

\section{I.5 Strive for perfection}

Womack and Jones (1996) suggest that the principles should be seen as an iterative process leading to perfection. Hines et al. (20II) argue that continuous improvement is the most important aim for the long-term success of the Lean program, since the improvement capability increases with time. If there is too much focus on short-term gains, the improvement work will stagnate or fade. Therefore, an important aspect of a Lean implementation is developing, challenging, and empowering employees (Antoni, 1996; Poksinska et al., 20I3). The purpose is to develop the employee's capability for detecting and solving problems. In addition, there is a positive interaction effect between these two drivers. In other words, the organization must have both a system 
to reveal problems and competent, authorized employees to detect and solve problems (MacDuffie, 1995)

\subsection{Public sector context}

The public sector consists of commonly financed institutions that provide society with basic services. This means the intangible The definition of public sector differs between countries, but institutions such as healthcare, education, social welfare, and the police are commonly included. Traditionally, three dimensions are regarded as important when differentiating the public sector from the private sector (Boyne, 2002). First, public-sector agencies are typically collectively owned by members of a society rather than by shareholders. Second, public-sector organizations are mainly financed by taxes rather than by customer fees. Third, public-sector organizations are controlled by political forces rather than market forces. Recently, there has been a strong focus on improving the public sector, regarding customer focus, quality, and process efficiency (Radnor and Osborne, 2013). However, these concepts are not always easy to interpret in the public sector.

\subsection{Customer in public sector}

The term customer is problematic in the public sector, both semantically and as a concept. Most important, there are no clear definition of who is a customer in the public sector (Fountain, 200I). For instance, in healthcare not only is the patient a customer, but also family members, caregivers, decision-makers, local communities, and tax payers (Poksinska, 2010; Shah and Robinson, 2008). The same discussion can be applied in other parts of the public sector. However, Alford (2002) suggests a typology consisting of two categories of customers: Citizens and clients. The citizens are the collective society that defines what the public organizations should do, expressed through political representation, which can be compared to private customers expressing preferences about the goods or service that is provided. The clients, on the other hand, directly receive the services, so interact with the service providers.

In the private sector, the direct consumer of the product or service is seen as the customer (Woodruff, 1997). Denhardt and Denhardt (2000) suggest that there are several problems with this view in the public sector. First, it is not only the direct client who must be served, but also those who are waiting for service or may need the service, although they are not seeking it. In addition, 
there are unwilling customers, such as those receiving a speeding ticket. Second, there are always clients with more resources and greater skill in putting forward their demands, which should not imply better treatment. Therefore, an important principle in the public sector is that the organization does not have the possibility to always meet the client's needs since there are political decisions regulating the level of the service (Brandt and Stigendahl, 2012). The ideas of equality and fairness in treatment are very important in the public sector (Denhardt and Denhardt, 2000).

\subsubsection{Quality in public sector}

In the same way as customer is a problematic term, it is also difficult to interpret quality in the public sector. Following Bergman and Klefsjö's (2010) definition that quality is "the ability to satisfy, or preferably exceed, the needs and expectations of the customer" (p. 23), several problems occur. First, there is more than one type of customer with needs and expectations. Second, the needs and expectations may be very different in some cases. For example, healthcare patients expect personal care, which is strongly associated with satisfaction (Cleary and McNeil, 1988). However, this does not directly imply that patients' medical needs and health outcomes are fulfilled, which also is important for the quality of care (Chassin and Galvin, 1998). Grönroos' (1984) service quality model covers both these aspects and suggests that the quality experienced from a service consists of quality in two dimensions: Technical quality and functional quality. The technical quality is the instrumental performance of the service, which can be described as what the customer receives from a service. This can frequently be objectively measured. Functional quality concerns how the service is provided, which is more subjective, since it is created in the interaction between service provider and customer.

\subsubsection{Processes in public sector}

The processes in public service have many similarities with service processes in general, since they are intangible and based upon a promise of what is to be delivered (Osborne et al., 2013). In addition, the objects in processes are not materialized products but information, and the customer is often involved in the process. 
Similar to service processes in general, public service consists of back-office and front-office processes (Zomerdijk and Vries, 2007). Front office processes are characterized by contact with the customer, while back office processes consist of activities that are performed without contact with customer (ibid). Customer contact does not necessarily means that the customer is physically present in the service delivery. Instead, customer contact can be seen as the level of interaction between customer and provider, meaning to what extent the customer can make demands on the design of service delivery systems (Schmenner, 1986). A general view is that the back-office processes are easier to control and to rationalize, due to the disturbances of customers in frontoffice processes (Zomerdijk and Vries, 2007).

\subsection{Lean Service}

Before Lean Production became commonly used in the public sector, it was needed to create a theory for Lean in the service sector in general (Souza, 2009). Using improvement concepts and ideas from manufacturing has been a trend since the 1970s, when Levitt (1972) suggested using production-line approaches for service processes. This is exemplified by McDonalds, whose processes follow production logic. When Lean was introduced in the service sector, it was primarily used in a similar way as in manufacturing. By using Lean principles, service organizations would reduce waste in their processes. Based on the use of Lean in manufacturing, Bowen and Youngdahl (1998) suggest five characteristics that also could be used in service organizations:

- Reduction of performance tradeoffs

o Operation goals of both internally-focused efficiency and customerfocused flexibility

- Flow production and JIT pull

o Minimize set-up time allowing for smoother flow

o JIT levels of both input and output

- Value-chain orientation

o Apply service blueprinting and value analysis to eliminate non-valueadding activities

- Increased customer focus and training

o Involve the customer in the design of the service package

- Train employees in customer service skills and behaviors

o Train customers in how to contribute to quality service 
12 Theoretical framework

\section{- Employee empowerment}

o Invest significantly in employees (skills, teambuilding, participation)

- Empower employees to leverage customers' value equation (benefits divided by price and other costs)

The five characteristics have big similarities with Womack and Jones' (1996) five principles, with a focus on customer value, value flow, continuous flow and pull, and striving for perfection through the empowerment of employees. However, the view that manufacturing concepts could more or less be copied to the service contexts has been criticized. Lovelock (201I, p6) argues that service organizations are different in several aspects:

Are the marketing skills developed in manufacturing companies directly transferable to service organizations? I think not. It is my contention that marketing management tasks in the service sector differing from those in the manufacturing sector in several important respects. Among the characteristics distinguishing services marketing from goods marketing are the nature of the product, the greater involvement of customers in the production process, greater difficulties in maintaining quality control standards, the absence of inventories, the relative importance of the time factor, and the structure of distribution channels.

When it comes to Lean, Ahlstrom (2004) explains that there are some contingencies that occur when Lean is used in the service context, and some principles must be translated in order to be meaningful for service organizations. Due to the involvement of customer in the service process, the principle of waste elimination is sometimes problematic, since the expectations from customers may differ. What is waste for one customer may be valuable for another. Another principle that can be problematic is zero defects. Although a low defect rate is crucial in many service processes, the high involvement of customers in the process makes it unrealistic to achieve zero defects. Parasuraman et al. (1985) suggest three aspects that are important in order to understand service quality. Firstly, the intangibility of services (Bateson, 1979; Lovelock, 20II) makes it difficult to set measurable specifications of services in the same way as in manufacturing. It may also be difficult for the organization to understand how the customer perceives the service (Parasuraman et al., 1985). Secondly, services have generally a large variability between different producers and different customers, making it 
difficult to ensure a consistent service delivery (ibid). Thirdly, the inseparable production and consumption of services (Zeithaml, 1981) means that the service cannot be engineered in a manufacturing plant. Instead, the service is often highly affected by the customer, and the service organization have therefore less control over the quality (Parasuraman et al., 1985). According to Ahlstrom (2004), prioritization and recovery from failure are more important in the service sector.

Some researchers suggest that Lean service should be radically different from Lean in manufacturing. Seddon et al. (20II) argue that reducing failure demand, which is demand caused by "failure to do something or something right for the customer" (Seddon and Caulkin, 2007 p. 17), is the most important aspect to increase efficiency in service processes. The time and resources needed to fulfill failure demand can be used to fulfill value demand, which customers demand. The major reason for failure demand is an inability of a system to absorb the variety of customer demands (Seddon et al., 201 I). A far-reaching standardization that reduces the flexibility of the system will lead to increased failure demand and decreased efficiency of the service process (Brandt and Stigendahl, 20I2). In addition, customers have different needs and expectations of the service, which means that it is difficult to find one definition of value and waste within the service organization.

\subsection{Lean in public sector}

The discussion about using Lean in the public sector has been a topic for almost 20 years, starting with the idea of using Lean in healthcare settings. From the beginning, articles were speculative rather than empirical. Researchers argued that Lean tools and techniques could be used in healthcare without any empirical data that could support (or contradict) this (Souza, 2009), or based on general experience and common sense (see e.g. Jacobs and Pelfrey, 1995; Spear, 2005; Whitson, 1997). The first empirically based studies on Lean in a healthcare context were published in 2002 (Souza, 2009). Those papers were mainly case studies of an implementation of a single Lean tool or principle in a healthcare setting, so lacked a view of Lean as a system of several practices, or full implementation (Radnor and Walley, 2008; Radnor et al., 2006). The studies were commonly published in medical journals and conducted in line with the medical tradition of focusing on measurable outcomes, such as decreased time spent on care, increased patient throughput, 
and reduced number of errors and incidents (Spear, 2005). Other studies reported quantitative outcomes such as improved problem-solving skills (Ballé and Régnier, 2007). However, these studies often neglected a critical perspective and did not problematize the results enough.

The pattern looks quite similar when looking at the public sector outside of healthcare, although the research on Lean implementations in this context is far less developed, but there are many speculations of the benefits (Bagley and Lewis, 2008; Bhatia and Drew, 2006; Krings et al., 2006) or case studies of implementations (Arlbjørn et al., 20I I; Barraza et al., 2009; Hines et al., 2008; Radnor et al., 2006; Radnor, 2010a). Still, there is a need for an overview of the research on Lean in public sectors outside of healthcare, with more connection to other theory fields than just conceptual representations of Lean (Brännmark, 2012). There is also a lack of deeper investigations of how Lean implementation influence organizations and the users, since most studies only present some indications of positive results, such as decreased lead times (Suárez-Barraza and Ramis-Pujol, 2010) and/or decreased stress among employees (Jaaron and Backhouse, 20I0; Radnor and Walley, 2008).

Regarding the discussion above, some conclusions and generalizations of Lean characteristics in the public sector can be made. In healthcare, Lean is primarily a process improvement methodology (Poksinska et al., 2013), so is often focused on implementing specific technology and tools rather than developing a culture of problem-solving. Radnor and Walley (2008) suggest that this is not exclusive to healthcare, but the public sector in general. Value stream mapping is the most used tool when working with Lean (Brännmark, 2012; Poksinska, 2010) The results of using Lean in the public sector are improvements from an internal perspective. Reduction of waiting and process time is given much more attention than increased value for the user (Radnor, 2010a; Radnor et al., 2012). An important precondition when implementing Lean is the basic stability that is needed to work with flow and pull in the processes. Basic stability means that the organization has established a capacity to meet demand, the right skilled staff and established or defined simple work methods (Radnor and Walley, 2008).

The current way of using Lean in the public sector has also been criticized due to the lack of system perspective, meaning that Lean is only used in limited parts of organizations (Radnor et al., 2012). There is a need to see the value 
flow from the user's perspective, which in most cases crosses functional and professional borders (de Souza and Pidd, 20I I). All in all, despite the number of papers and studies regarding Lean in the public sector, there are some gaps that must be filled. In line with the doctrines of new public management (NPM), the focus of public management theory has been on the efficiency of internal administrative processes (Hood, 1991; Osborne et al., 2013). As a consequence, there has been a trend to use concepts from research conducted in manufacturing contexts, of which Lean is one of the most well-known and used (Arlbjørn et al., 20l I). The customer is seen as a passive receiver of the services, rather than an active part of the process, since the processes in public service organizations are managed in the same way as manufacturing processes, rather than as service processes (Osborne et al., 2013). Therefore, there is a need for a discussion about the use of Lean in relation specific preconditions concerning quality, customer and processes in the public sector. 



\section{Methodology}

This chapter describes the research approach in this thesis and the methodologies for collecting and analyzing the data upon which the thesis is built. The thesis is built on seven case studies, mainly consisting of qualitative data, since this is suitable for the research questions (Merriam, 1998).

\section{I Research Overview}

Table I shows an overview of the connection of cases to research questions. The three papers used data from seven cases, of which I was involved in four. Most of the cases were studied within a Vinnova'-funded project about Lean leadership in healthcare. I participated in a later part of the project. The other project in which I participated was about Lean at the social service authority. It was founded by the municipality of Linköping, in which I studied the implementation of Lean in the social service authority from November 201 I to June 2014.

Table I: Overview of research design

\begin{tabular}{|l|l|l|l} 
Paper & Cases & Research questions & Context \\
\hline Paper I & $\begin{array}{l}\text { All seven } \\
\text { cases }\end{array}$ & $\begin{array}{l}\text { RQI: How is Lean production used in } \\
\text { practice? }\end{array}$ & $\begin{array}{l}\text { Manufacturing; Healthcare; } \\
\text { Social service }\end{array}$ \\
\hline Paper 2 & Alpha & $\begin{array}{l}\text { RQ2: Which Lean principles, methods, } \\
\text { and tools are used in the public sector? }\end{array}$ & Healthcare \\
\hline Epsilon & $\begin{array}{l}\text { Zeta } \\
\text { RQ3: What are the possibilities and } \\
\text { limitations of using Lean in the public } \\
\text { sector? }\end{array}$ & $\begin{array}{l}\text { RQ2: Which Lean principles, methods, } \\
\text { and tools are used in the public sector? }\end{array}$ & Social service \\
\hline Eta & $\begin{array}{l}\text { RQ3: What are the possibilities and } \\
\text { limitations of using Lean in the public } \\
\text { sector? }\end{array}$ & \\
\hline
\end{tabular}

I Vinnova is a Swedish governmental agency for innovation systems 
The rest of the cases were studied in projects in which I did not actively participate, but studied the dataset collected in those cases. Table 2 is an overview of the methodology used in the cases, and in which cases I was involved.

Table 2: Overview of cases and methodology

\begin{tabular}{|l|l|l|l|}
\hline $\begin{array}{l}\text { Case } \\
\text { (pseudonym) }\end{array}$ & Organization & Methodology & $\begin{array}{l}\text { Involvement in } \\
\text { data collection }\end{array}$ \\
\hline Alpha & Primary care unit & Interviews, observations & \\
\hline Beta & $\begin{array}{l}\text { Pharmaceutical } \\
\text { company }\end{array}$ & $\begin{array}{l}\text { Interviews, observations, } \\
\text { shadowing }\end{array}$ & Jointly \\
\hline Gamma & $\begin{array}{l}\text { Manufacturing } \\
\text { company }\end{array}$ & Interviews & - \\
\hline Delta & Municipality & Interviews & - \\
\hline Epsilon & Primary care unit & Interviews, observations & Jointly \\
\hline Zeta & Healthcare clinic & Interviews & Jointly \\
\hline Eta & Social service office & Interviews, observations, & Major \\
\hline
\end{tabular}

\subsection{Case methodology}

This theme aims to investigate how Lean is implemented in the public sector organization and what possibilities and limitations it has. There is a need to investigate the connection between Lean context and the public-sector context. The purpose is of high complexity and there is a lack of research about the subject, which therefore requires a explorative approach (Benbasat et al., 1987). In line with the recommendations from methodology theory, a case-study approach was chosen for the studies conducted in this thesis (Bryman and Bell, 2003; Gummesson, 2003; Yin, 2009). Of special importance in this thesis is that the case study was used to investigate a phenomenon within the context, rather than independent from it (Gibbert et al., 2008; Hartley, 2004). 
Case studies are often criticized for a lack of possibilities to generalize conclusions (Flyvbjerg, 2006). However, as Flyvbjerg (2006) suggests, case studies can be used to falsify a hypothesis, in the meaning of Popper (2005). The experience of a single case is often more valuable than formal generalization. According to Yin (2009), case studies can be used for theoretical propositions rather than populations. In this thesis, several cases are used, which strengthen the possibility to find patterns and decrease the risk for being criticized due to uniqueness or artificial conditions regarding the case (Yin, 2009). In addition, the case design can be replicated for the other cases. In this study, this has been used to some extent, since interview questions and observation protocols were used in several cases. According to Yin (2009), this strengthens the analytical conclusions of the study.

The case-study methodology provided deeper insight into the organizations and covered several perspectives. This was needed since the aim for the thesis is theory-generating rather than theory testing. The case study has the advantage of providing a possibility to explore and understand complex phenomena that are specific to context and is therefore suitable in this thesis (Yin, 2009).

\subsection{Description of cases}

Alpha is a publicly owned care center that has approximately 25 employees, including doctors, nurses, dieticians, and administrative staff. It provides primary healthcare to a small municipality of approximately 2,500 citizens. Lean was initiated to improve the working environment for employees, which was very stressful. The implementation aimed to build a culture where employees conducted and drove the continuous improvement work.

Beta is a biopharmaceutical company. The company has well-developed work with Lean and was awarded the Swedish Lean Prize in 2008. It is located in a region known for hosting several companies and public organizations working with Lean. This made it possible to recruit people with high experience with Lean work.

Gamma is a manufacturing company producing industrial turbo-machinery and has around 2,800 employees in Sweden. The company started work with Lean 
in 2003 to increase productivity. The implementation was operationalized through the use of two Lean tools, $5 \mathrm{~S}$ and visual management.

Delta is a unit responsible for elder care in a municipality of 16,000 citizens. The use of Lean started in 2004. However, this did not imply a radically new way of working, compared to the earlier improvement work that had been conducted since 1992. The main tools that were used in the organization were value stream mapping and $5 \mathrm{~S}$.

Epsilon is a care center with approximately 35 employees and provides primary healthcare in one of the municipalities in Stockholm. Its reason for working with Lean is to increase quality and decrease waiting time to meet the competition from newly established private care centers. The implementation is managed in discrete projects focused on specific problems within the care center.

Zeta is a hospital physiology unit with approximately 20 employees, mostly biomedical technicians. It is specializes in investigations of the heart, blood vessels, and lungs. The unit already had an extensive improvement work before the implementation of Lean. The manager of the unit is the primary driving force in the Lean work.

Eta is a social service office, providing social services to a municipality of 150,000 citizens. There are approximately 300 social workers. Lean was introduced to improve efficiency and user focus. The working groups had a high degree of independence in how to conduct their Lean work. In other words, there were few guiding principles from management. Some groups, representing approximately 30 percent of the employees, participated in an education in Lean for four days.

\subsubsection{Interview method}

Interviews are probably the most common method in qualitative research and offer a flexible and powerful way of getting knowledge (Bryman and Bell, 2003; Kvale, 2007). In this thesis, interviews were used in all the studied cases, and in most as a main source of knowledge. The interviews have generally been semistructured, in which the interview is largely prepared and follows a structure, but also leaves some possibility to ask follow-up questions, and leave out or reorder questions, depending upon the answers (Bryman and Bell, 2003). This 
also gives the possibility to adjust the interview to the interviewee's communication style. In some cases, the interviewee gave quite short answers, which required the ability to instantly ask follow-up or additional questions. In a few cases, the number of questions was reduced, since the interviewee gave quite long answers (Kvale, 2007). However, in order to increase the possibility to compare the answers between different cases and interviewers (Bryman and Bell, 2003), the intention was to adhere to the interview guide as much as possible.

In most cases, the interviewer was alone, but the interviews were recorded and transcribed, so all the writers of the appended papers could study the answers from all interviews to get the whole picture. In order to analyze the interviews, content analyses were used in order to seek pattern-matching between categories that emerged from the data and the interview themes. For more detailed information of the interviews and the interviewees, see table 3.

In the Eta case, two focus groups were also used to increase the number of interviewees and see the different views among the employees. The major task of the focus group interviewer was to facilitate a discussion about different viewpoints by introducing topics rather than asking direct questions (Kvale and Brinkmann, 2009; Kvale, 2007). The focus group interviews were used primarily in an early, exploratory phase of the study, which was in line with Kvale and Brinkmann (2009). The focus group interviews were built on the same topics as the one-on-one interviews, but focused on the most important questions due to time constraints. The interviews were recorded and transcribed in the same way as the one-to-one interviews. When analyzing focus group interviews, it was difficult to both analyze what is actually said and how the group members are interacting (Bryman and Bell, 2003). Therefore, the analysis did not emphasize the interaction between group members, since this was not an important aspect of the research. 
Table 3: Interviews performed at case organizations

\begin{tabular}{|c|c|c|c|}
\hline Case & $\begin{array}{l}\text { \# of } \\
\text { inter- } \\
\text { views }\end{array}$ & Main focus of interviews & Interviewed \\
\hline $\begin{array}{l}\text { Alpha } \\
\text { (Primary } \\
\text { care unit) }\end{array}$ & 6 & $\begin{array}{l}\text { - How Lean production was defined } \\
\text { and perceived by the organization } \\
\text { - How Lean production was } \\
\text { implemented } \\
\text { - How the improvement work was } \\
\text { organized } \\
\text { - How the roles and responsibilities } \\
\text { of employees changed after Lean } \\
\text { production was implemented }\end{array}$ & $\begin{array}{l}\text { - one manager (doctor) } \\
\text { - two doctors } \\
\text { - three nurses }\end{array}$ \\
\hline $\begin{array}{l}\text { Beta } \\
\text { (Pharmace } \\
\text { utical } \\
\text { company) }\end{array}$ & II & $\begin{array}{l}\text { - Reasons for implementing Lean } \\
\text { - Development of work over time } \\
\text { - Role of management, attitudes } \\
\text { toward Lean } \\
\text { - Results of Lean work and how } \\
\text { problems were solved }\end{array}$ & $\begin{array}{l}2009 \\
\text { - one factory manager } \\
\text { - one production manager } \\
\text { - three first line managers } \\
\text { - six operators } \\
2011 \\
\text { - one factory manager } \\
\text { - one production manager } \\
\text { - two first line managers } \\
\text { - two operators }\end{array}$ \\
\hline $\begin{array}{l}\text { Gamma } \\
\text { (Manu- } \\
\text { facturing } \\
\text { company) }\end{array}$ & 46 & $\begin{array}{l}\text { - First phase: } \\
\text { - Description of first contact with } \\
\text { Lean } \\
\text { - Personal experience of Lean } \\
\text { introduction } \\
\text { - Second phase: } \\
\text { - Questions about a specific project }\end{array}$ & $\begin{array}{l}\text { - one managing director } \\
\text { - one division manager } \\
\text { - two production managers } \\
\text { - two floor managers } \\
\text { - three production } \\
\text { supervisors } \\
\text { - one Lean coordinator } \\
\text { - one Lean implementer } \\
\text { - one production planner } \\
\text { - } 31 \text { operators }\end{array}$ \\
\hline
\end{tabular}




\begin{tabular}{|c|c|c|c|}
\hline $\begin{array}{l}\text { Delta } \\
\text { (Munici- } \\
\text { pality) }\end{array}$ & 8 & $\begin{array}{l}\text { - Reasons for implementing Lean } \\
\text { - Development of work over time } \\
\text { - Role of management, attitudes } \\
\text { toward Lean } \\
\text { - Results of Lean work and how } \\
\text { problems were solved }\end{array}$ & $\begin{array}{l}\text { - one facilitator } \\
\text { - one quality manager } \\
\text { - two elder-care managers } \\
\text { - four elderly care } \\
\text { employees }\end{array}$ \\
\hline $\begin{array}{l}\text { Epsilon } \\
\text { (Primary } \\
\text { care unit) }\end{array}$ & 8 & $\begin{array}{l}\text { - How Lean production was defined } \\
\text { and perceived by the organization } \\
\text { - How Lean production was } \\
\text { implemented } \\
\text { - How the improvement work is } \\
\text { organized } \\
\text { - How the roles and responsibilities } \\
\text { of employees changed after Lean } \\
\text { production was implemented }\end{array}$ & $\begin{array}{l}\text { - one manager } \\
\text { (physiotherapist) } \\
\text { - four doctors } \\
\text { - two nurses } \\
\text { - one secretary }\end{array}$ \\
\hline $\begin{array}{l}\text { Zeta } \\
\text { (Health } \\
\text { care } \\
\text { clinic) }\end{array}$ & 10 & $\begin{array}{l}\text { - How Lean production was defined } \\
\text { and perceived by the organization } \\
\text { - How Lean production was } \\
\text { implemented } \\
\text { - How the improvement work was } \\
\text { organized } \\
\text { - How the roles and responsibilities } \\
\text { of employees changed after Lean } \\
\text { production was implemented }\end{array}$ & $\begin{array}{l}\text { - one manager (doctor) } \\
\text { - two doctors } \\
\text { - one nurse } \\
\text { - two secretaries } \\
\text { - four biomedical analysts }\end{array}$ \\
\hline $\begin{array}{l}\text { Eta } \\
\text { (Social } \\
\text { insurance } \\
\text { office) }\end{array}$ & 6 & $\begin{array}{l}\text { - General questions about Lean in a } \\
\text { social-service context, enablers and } \\
\text { barriers for Lean learning and } \\
\text { personal development } \\
\text { - Role and responsibilities of } \\
\text { managers and employees } \\
\text { - User focus improvement work } \\
\text { - Expected and achieved results of } \\
\text { Lean work }\end{array}$ & $\begin{array}{l}\text { - two group managers } \\
\text { - four social workers }\end{array}$ \\
\hline
\end{tabular}




\subsubsection{Document studies}

In the Eta case, document studies were used as a complement to interviews and observations. In particular, protocols from meetings with the steering committee were studied, which provided insights in decisions regarding the Lean work. In addition, a final report from the implementation project was studied, which provided an overview of the work in the groups, as well as the results that were achieved. In the report, quantitative results from the IT system were reported, which were used to some extent in the study. The biggest advantage of using these documents is that they are stable (meaning that they can be reviewed over and over again) and exact (meaning that they contains exact names, references, and details of events) (Yin, 2009). However, as Gummesson (2003) suggests, internal documents are not always the most reliable sources. Therefore, this was primarily used to triangulate data from interviews and observations.

\subsubsection{Participative observations}

In several cases (Alpha, Beta, Epsilon, Eta), participative observations of meetings were performed. In line with Merriam (1998), participative observations were used when situations, activities, or events could be observed firsthand in the natural field setting. In three cases (Alpha, Beta, Epsilon), researcher roles were observers-as-participants, meaning that the main role was to observe but limited participation was also allowed (Gold, 1958). In those cases, a formalized observation sheet from Elg (200I) were used. The main topics of the observation sheet were: time, place and participants, aim with the meeting, use of metrics and roles of participants and leaders. In general, at least two researchers observed every meeting, which made it possible to compare the observations to strengthen the validity. In the case of Eta, the researcher participated in the meetings to a greater extent, which provided an opportunity to be active (Gold, 1958). In those meetings, no structured observation sheet was used, but interesting phenomena relating to the research topic were recorded.

\subsubsection{Survey}

Quantitative methods are commonly used for a deductive approach (Bryman and Bell, 2003) but can also be used in case studies (Gummesson, 2003). In the study of the social service, a questionnaire was used to increase the number of 
respondents, in comparison to what was possible with interviews (Bryman and Bell, 2003). Another advantage is that there are no variations in questions, and the respondent can be anonymous (Bryman and Bell, 2003). However, the use of questionnaires often requires an established theory as basis for developing a hypothesis, and therefore typically a deductive approach (Bryman and Bell, 2003). In this case, the purpose was to find areas for improvement by comparing the actual case and theory. This was done by constructing a questionnaire measuring $6 \mathrm{I}$ statements on two scales: importance and compliance. In that sense, the questionnaire simultaneously tested theory and generated new theory. The statements were divided into 12 categories, which were considered as important for building a Lean culture:

- Organizational learning

- Strategy, objectives, and follow up

- Governance and organization of improvement work

- Improvement culture

- Cooperation within and between teams

- Daily management

- Leadership

- User focus

- Process orientation

- Problem solving

- Channels of communication

In addition, the respondents were asked to estimate how Lean implementation had influenced the user value, working environment, productivity, and economy. The questionnaire was sent out through on-line survey software during June and August 2013 to all employees at the case organization Eta. The response rate was 55.9 percent. The answers were analyzed based on three dimensions: Compliance, importance, and the gap between them. Values significantly higher and significantly lower than average were noted and analyzed. The method of gap analysis has earlier been used by e.g. Brown and Swartz (1989) and Parasuraman et al., (1985) measuring the divergence between an expected value and a perceived value. 


\subsection{Quality of research}

The traditional definition of validity and reliability is closely connected to quantitative measurement, so is not suitable in research that is primarily quantitative, as in this thesis (Bryman and Bell, 2003). However, Yin (2009) suggests that validity and reliability still can be used to assess quality in case studies, but the concepts need to be reinterpreted.

\subsection{Reliability}

The traditional way of describing reliability is that the result of a study would remain the same if it was done again (Bryman and Bell, 2003). However, this is impossible in many case studies since they are, by their nature, time- and context-specific. Instead, reliability can be seen as a hypothetical test that another researcher would come to the same findings and conclusions when researching the same case at the same time (Yin, 2009). Yin recommends that the research process should be carefully recorded and documented. In this case study, the interviews were recorded, and the recordings were transcribed. In cases where researchers performed participative observations, recordings of the meetings were made. If there were two or more researchers observing the meetings, the recordings were compared and discussed.

\subsubsection{Construct validity}

According to Yin (2009), there are three dimensions of validity: Construct, internal, and external. Construct validity tests that the constructs used in the study actually measure what is intended to be measured (Bryman and Bell, 2003). In order to achieve a high construct validity, Yin (2009) suggests that two steps must be considered: Finding theoretical concepts that can be associated with the phenomena; and finding how to measure these concepts. In order to increase the construct validity in this study, several methods were used (Yin, 2009). In most of the case studies, several methods for data collection were used, such as interviews, participative studies, and document studies. In addition, feedback seminars for every case organization were arranged, which gave the organizations opportunities to comment on the perceptions from the study, which increased the construct validity (Eisenhardt, 1989; Yin, 2009). 


\subsubsection{Internal validity}

The internal validity is used for explanatory research designs and describes how well the researcher has succeeded in proving that event $y$ is caused by event $x$, rather than uninvestigated event $z$ (Yin, 2009). Therefore, it is important to discover the underlying theoretical reasons for the relationships (Eisenhardt, 1989). The hypotheses in this thesis are well-connected to, and founded in, existing theory, which strengthens the internal validity (Eisenhardt, 1989).

\subsubsection{External validity}

External validity determines if the findings are valid in another context, and if the results are generalizable (Yin, 2009). In this thesis, the same interview questions were used in several cases to increase the population of cases investigating the same phenomena and, therefore, the external validity (Eisenhardt, 1989). In addition, when the questionnaire was constructed, the external validity could be increased by using questions from earlier, wellestablished questionnaires. When the questionnaire was made, it was validated by five respondents from different parts of the public-service sector and could be improved due to comments from the respondents. 



\section{Summary of appended papers}

This discussion on this thesis is based on three papers, which are summarized below. Paper $\mathrm{I}$ is a working paper that compares how Lean is described in theory and how it is used in real cases. Paper 2 is published in Health Organization and Management and discuss the employees' new roles, responsibilities and job characteristics in healthcare organizations working with Lean. Paper 3 discuss possibilities and limitations of Lean in social service and was presented on the QMOD conference in 2014. The full version of the papers can be found in the appendix.

\section{I Paper I - The rhetoric and reality of Lean production}

Unlike many other quality concepts, Lean is derived from practice and described in numerous academic and management articles and books. In this paper, the idea was to challenge the simplified picture of a single, well-defined entity that entails a certain range of predictable outcomes. Instead, an investigation of what organizations do when they "do Lean" was performed. The lack of precision in describing Lean has undesirable consequences both for researchers and practitioners. Researchers may experience problems with the validity of studies about Lean and the effects on organizations. Practitioners, on the other hand, are faced with sometimes unrealistic expectations of results and organizational span.

Paper I analyzed seven case organizations, from both industrial and publicsector contexts, that had worked with Lean for various lengths of time. The cases were analyzed in three dimensions (inspired by Zbaracki, 1998): Technical, rhetorical, and organizational. The technical dimension represented the methods and techniques associated with the Lean initiative. The rhetorical dimension represented overall principles, goal formulations, and expected outcomes from the Lean work. The organizational dimension is about the actors of the Lean work (both initiators and drivers) and in which processes the work is performed.

\section{I.I Lean in rhetoric and in practice}

In general, there were large differences between the popular Lean presentations, well-known books and articles that have been influential in the 
common picture of Lean (e.g. Liker, 2004; Womack and Jones, 1996; Womack et al., 1990) and how Lean was used in practice. In reality, it was difficult in some cases to separate the Lean work from a previous improvement work, and therefore difficult to set a distinct starting point. In this sense, Lean signified an incremental change, rather than a revolutionary change from mass production to Lean production, which is often described in management literature (see e.g., Womack et al., 1990). The most important practices were continuous improvement (which was used in all cases), value stream mapping, and 5S. Tools associated with production, such as Kanban, Andon, and Poka Yoke, were used to a much lesser extent, especially in nonmanufacturing settings.

Table 4 shows an overview of the most important aspects of the technical, rhetorical, and organizational dimension of Lean work in the case organizations. The table also provides an overview of the most important outcomes.

Table 4: Summary of cases

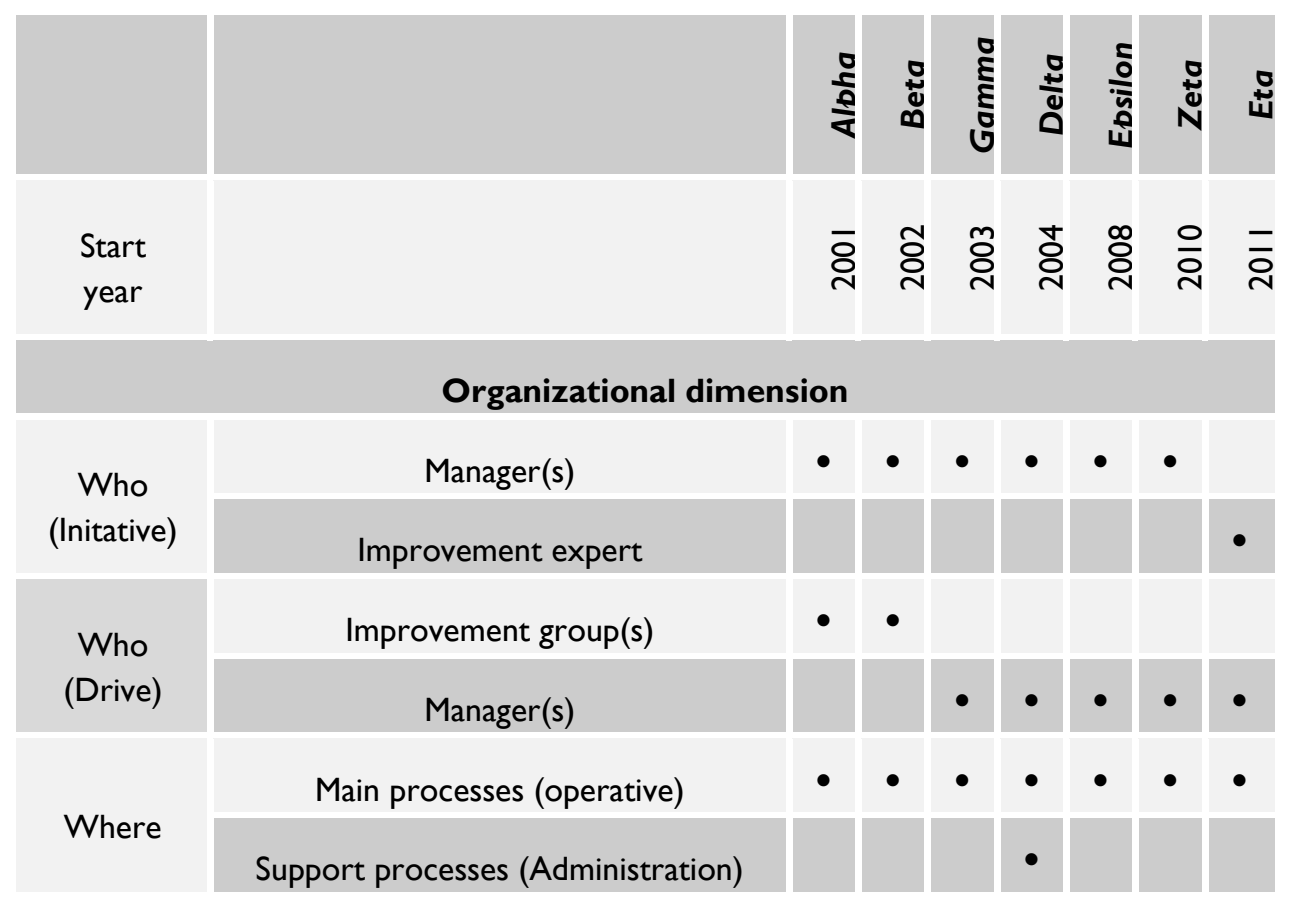




\section{Rhetorical dimension}

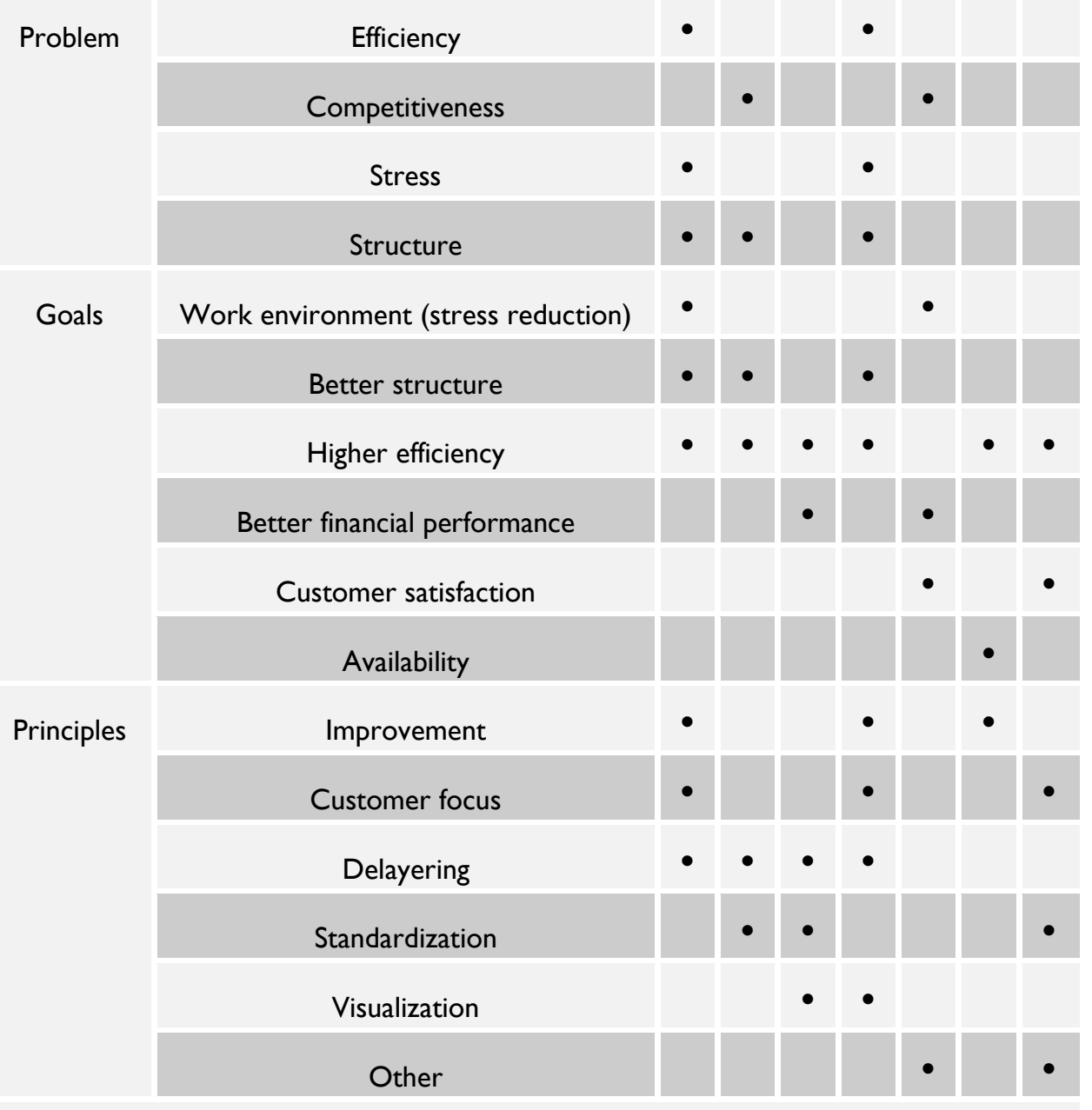

\section{Technical dimension}

Techniques

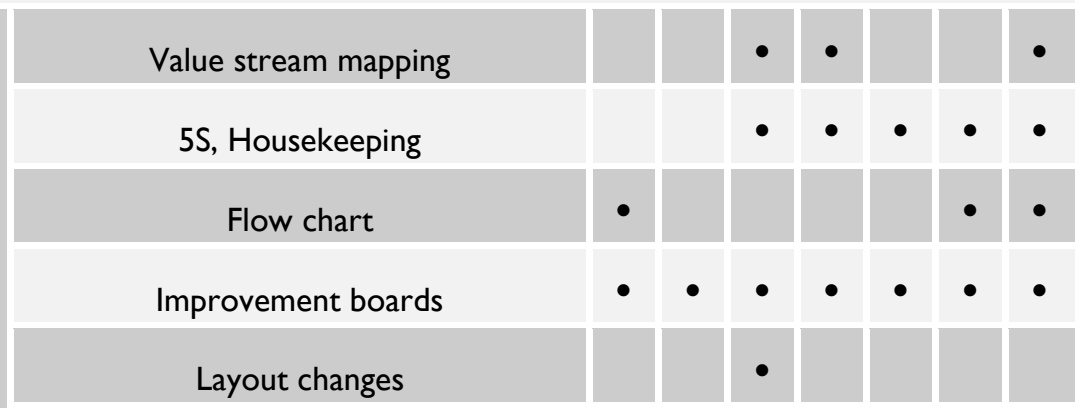

Production leveling 
32 Summary of appended papers

\begin{tabular}{|c|c|c|c|c|c|c|c|c|}
\hline & PDCA & & & & & & - & $\bullet$ \\
\hline & Pulse meetings & & $\bullet$ & $\bullet$ & & $\bullet$ & & $\bullet$ \\
\hline \multirow[t]{4}{*}{ Metrics } & OEE & & $\bullet$ & & & & & \\
\hline & General metrics (SQLE) & & $\bullet$ & & & & & \\
\hline & Availability & & & & & $\bullet$ & & \\
\hline & Other & & & & & & & $\bullet$ \\
\hline \multicolumn{9}{|c|}{ Outcomes } \\
\hline \multirow[t]{10}{*}{ Changes } & Work environment & - & & & & & & \\
\hline & Layout adjustments & & & $\bullet$ & & $\bullet$ & & \\
\hline & Availability & $\bullet$ & & & & & & \\
\hline & Increased cooperation & & $\bullet$ & & & $\bullet$ & $\bullet$ & \\
\hline & Work/process standardization & $\bullet$ & $\bullet$ & & $\bullet$ & & & \\
\hline & Efficiency & & & $\bullet$ & $\bullet$ & $\bullet$ & & \\
\hline & Financial results & & & $\bullet$ & $\bullet$ & & & \\
\hline & New perspectives and terminology & $\bullet$ & $\bullet$ & $\bullet$ & $\bullet$ & $\bullet$ & $\bullet$ & - \\
\hline & Customer satisfaction & & & & - & & & \\
\hline & Other & & & & & & - & - \\
\hline
\end{tabular}

\section{Organizational dimension of Lean}

Many established descriptions of Lean implementation advocate a structured, planned approach (cf. Liker, 2004; Womack and Jones, 2003). However, in the investigated cases, the organizations that had worked with Lean for a rather long time tended to have a team-driven improvement work, while the improvement work was more manager-driven in the other cases. This shows that the maturity of the Lean work is important for the employee empowerment and that management had a different role than suggested in the 
literature, in which there is a strong focus on leadership behavior (cf. Emiliani, 2006). The main role of management was to encourage employees to make improvement suggestions.

Requesting improvements is the biggest part of what managers do (First line manager at Beta)

Although leadership was important when the Lean work was initiated, the need for strong leadership decreased when the organization had, to at least some extent, empowered the employees and transferred the initiative in the improvement work (Poksinska et al., 2013). However, a difference between the public sector organizations and the manufacturing organization was the involvement of top managers. In manufacturing, the Lean work was usually driven from top management and on the whole organization. In public sector, the groups were more independent in how the Lean work was managed. Therefore, it is mainly the group managers that have the initiative in the improvement work.

\section{Technical dimension}

In all of the cases, some kind of improvement boards was used. This indicates that this is a common tool in all Lean organizations, both in service and in manufacturing. The purpose of improvement boards are to visualize the improvement work, and are often connected to weekly pulse meetings. Another tool that has been used is value stream mapping, although there are different purposes for VSM in manufacturing and in public sector. In manufacturing it was used as a tool for analyzing the value stream, aiming at achieve flow and pull in the process, while in public sector it was used to map the process as a start of the work with employee-driven improvement work.

$5 \mathrm{~S}$ were used in almost every case, but to a different extent. In the manufacturing companies, it was a very important tool that played a central role in the Lean work. In the public sector, where the flow is mainly nonphysical, the tool was not as important and the use of it not as frequent as in manufacturing.

Regarding the results, some patterns could be observed. A general result in all cases were that the Lean work led to a new terminology and new perspectives, 
so that employees and managers started to think about the daily work in terms of value, flow and waste.

I think I have become more (...) into looking at the value and (...) the value flows and really focus on what is not good and see opportunities. (Employee at Zeta)

In some of the cases, important results were increased cooperation (both vertically and horizontally); more standardized work processes; and increased efficiency.

\section{Rhetorical dimension of Lean}

The rhetorical dimension also showed some differences between Lean in reality and descriptions in literature. In literature, a main driver for Lean is often presented as a set of problems related to mass production, e.g. high level of work-in-progress and inventory, high defect rate and low flexibility (Krafcik, 1988; Liker, 2004). In reality, the Lean work was not preceded by such specific problems in most cases, but was justified by quite general, vague terms such as competiveness, efficiency, and customer satisfaction. The inspiration came from a wide range of sources, such as other organizations, consultants, and courses or seminars. The overall principles for the Lean work were generally described as improvement and de-layering, which was quite similar to the two main principles in TPS, continuous improvement and respect for people (Toyota Way, 200I). However, in practice, Lean was not focused so much on the physical working environment as on the employees' involvement in improvement work.

\section{Outcomes from Lean work}

The problem with the lack of predictable, measurable outcomes of Lean has been stressed in previous studies (Brännmark, 2012; Hasle et al., 2012; Langstrand, 2012; Pettersen, 2009). The investigated cases do not contradict this statement. In some cases (such as Gamma, Delta, and Epsilon), there were measurable outcomes, but it was very difficult to prove that they were an effect of the Lean intervention. However, introduction of new concepts, perspectives, and terminology seemed to be the most obvious effect. Employees and managers started to look for waste in the processes. In addition, empowering employees in improvement work was a common 
outcome, which change the way of communicating between managers and employees. From being mainly one-way communication, the problem-solving activities increased the level of two-way communication in several organizations.

Paper I argues that researchers should discuss Lean based on what organizations actually do, rather than based on descriptions from management books. From being described as essentially technical in many management books, Paper I shows that Lean is more about social issues and empowering employees. This is most obvious in contexts far from manufacturing.

\section{Conclusions}

The most important conclusion from paper $I$ is that there are some deviations between Lean, as it is described in management literature, and as it is used in practice. Moreover, how it is used varies between cases. When analyzing Lean, it is therefore important to avoid seeing Lean as a homogenous concept. In addition, this study suggests that introducing Lean into new context also makes it more loosely defined. Therefore, research on Lean implementations should use multiple sources of data to find out what the organizations actually do under the Lean label.

\subsection{Paper 2 - Lean in healthcare from the employees' perspective}

The importance of the employee's perspective in Lean initiatives was known as early as 1977 (Sugimori et al., 1977), but only lately has it received more attention (Joosten et al., 2009). However, especially in the healthcare context, there is a lack of understanding how the employees' roles, responsibilities, and job characteristics are influenced by a Lean implementation. The aim of the paper was to contribute to toward a deeper understanding of the new roles, responsibilities and job characteristics of the employees in Lean healthcare organizations. Table 5 presents the core job characteristics in the Lean manufacturing context. 
36 Summary of appended papers

Table 5:Core job characteristics in Lean manufacturing (based on Treville and Antonakis, 2006)

\section{Job \\ characteristics}

Increased skill variety

\section{Definition}

Extent to which the job requires an employee to utilize multiple high-level skills

\section{Lean practices}

\section{Cross training}

Job rotation

Multiskilling

Problem-solving

Participation in $\mathrm{Cl}$

\section{Cross-training}

Flow based layout

Teamwork

\section{Increased feedback}

Extent to which an employee receives feedback on job performance

Visual management

Brief daily meeting

Flow-based layout

Increased responsible autonomy

Extent to which an employee has responsibility and decision-making authority

\section{Self-managed teams (decentralization of} authority, power sharing, participation in decision making)

Participation in $\mathrm{Cl}$

\section{Decreased choice autonomy}

Extent to which an employee has freedom concerning work procedures and timing

Takt time

Cycle time

Increased work facilitation
Extent to which actions are directed toward removing obstacles that inhibit employee performance
Coaching and supporting leadership style

Production leveling

Poka-Yoke (mistake proofing)

$5 S$ (work place organization) 
The study consists of three case organizations that worked with Lean for several years. The organizations were given names that reflected the basic characteristics of their Lean implementation: Lean Culture, Lean Leadership, and Lean Projects. Lean Culture is a primary care center in a small municipality in western Sweden. The name was chosen based on the implementation approach, which focused on building a culture in which employees are empowered in decision-making and are responsible for the improvement work. Lean Leadership is a hospital physiology unit with approximately 20 employees. The name was chosen due to the strong, driving leadership that characterized the organization. Lean Projects is another primary care center in a municipality in Stockholm. The name Projects was given since the Lean was mainly executed in discrete projects focusing on one specific problem within the care center. The methodology for data collection was mainly semi-structured interviews with employees and managers. The interviews topics related to the Lean work and how it was implemented. In addition participant observations of meetings and document studies were made.

\subsection{Change in roles, responsibilities and job characteristics}

Ten practices associated with Lean were used in the case organizations, continuous improvement, self-managed teams, visual control, brief daily meetings, standardized work, coaching and supporting leadership style, and 5S. The paper suggests that these practices influenced the role, responsibilities, and job characteristics of a Lean healthcare organization in several ways.

\section{Skill variety}

The skill variety increased due to the use of continuous improvement in the organizations. In addition to employees' traditional clinical activities, they were encouraged to come up with ideas, and in various extents take decision upon and realize the ideas.

\section{Task identity}

The task identity increased somewhat due to the increased flow orientation. However, the complexity of the healthcare context made it difficult to apply job rotation and multiskilling. This would have further increased the skill variety (Treville and Antonakis, 2006). 


\section{Feedback}

The feedback also increased due to the visual control and daily meetings that were common in the case organizations, although the nature of care processes limited the possibilities to provide instant feedback metrics connected to process performance.

Responsible autonomy

The responsible autonomy normally increased through self-managed teams, decentralization of authority, power sharing, and participation in decisionmaking. However, the healthcare context was characterized by its hierarchical system, and employees had a strong affiliation to their professional group. These aspects are barriers to a team-based organization, so limit increasing responsible autonomy.

\section{Choice autonomy}

The choice autonomy usually decreases in Lean manufacturing organization due to the standardization of work procedures. In healthcare, standardization is used to a limited extent due to a strong tradition of highly skilled individuals who act on their own decisions when treating patients. Therefore, concepts such as takt time and cycle time are rarely used in a healthcare context. For work facilitation, there was limited use of the Lean practices that normally increase this job characteristic. The only tool that was frequently used was the 5S, whereas production leveling, Poka Yoke, and coaching and supporting leadership style were only used to a minor extent. A coaching leadership also contradicts the tradition within healthcare that the most skilled professionals become leaders, although they sometimes have limited knowledge about how to motivate, engage, and coach employees.

\subsubsection{Main conclusions}

The study concluded that the Lean implementation greatly influenced the role, responsibilities, and job characteristics within the healthcare context, both positively and negatively. Lean positively influenced the skill variety due to the additional tasks related to the improvement work. An example of the negative influence is the decreased choice autonomy. However, in conclusion, the teamwork, value flow orientation, and continuous improvement built 
motivation and strengthened commitment in the case organizations. This study suggests that these practices should be in focus when implementing Lean in the healthcare setting.

\subsection{Paper 3 - Possibilities and limitations of Lean in social service}

The public-service sector is facing big challenges due to an ageing society, increased demands on public services, and tighter budgets. In order to meet these challenges, Lean has become more and common. Despite this, there is a lack of empirical research about how Lean is implemented in the public sector outside of healthcare (Brännmark, 20I2) and how Lean is translated to a service context (Radnor and Osborne, 2013). The aim of this study is to contribute to the knowledge about how Lean is used in the public-sector context and the possible benefits and limitations of Lean in the municipal public sector.

The study is built on a social service case organization that had worked with Lean since 20ll. The research consisted of both qualitative and quantitative data collection. The qualitative data consisted of interviews and focus groups, documentation from meetings, and participative studies. The quantitative data consists of a questionnaire that was sent out during Spring/Summer 2013, with a response rate of 55.9 percent. In the questionnaire, every statement was measured in two dimensions: Compliance with the statement, and the importance of the statement. By calculating the difference between the compliance and importance, an analysis was based on the employees' apprehension about what was important in the context, rather than using a generalized construct.

\subsection{Possibilities and limitations}

Within the case organization, there are both back office processes and front office processes. Our results show that Lean has little relevance for the improvement of front-office processes, since the service characteristics such as inseparability and heterogeneity makes limit the possibility to apply production based concepts. In such processes, value cannot be specified in advance since the value is primarily created in interaction between social worker and user. This has implications for both the technical and functional quality dimension. Regarding the technical quality, a limitation is that there is no possibility to 
define a solution that fits every user. Regarding the functional quality, this depends on the individual preferences of the user.

The back office processes can be defined as the flow of information needed to make decisions on the cases. In those processes, the characteristic of service does not apply to the same extent, which makes it possible to use some of the Lean tools and technologies. The main objective when applying Lean in back office processes is to shortening the lead time, increase efficiency and achieve a consistent quality. This puts focus on the technical dimension of quality. The improvements were achieved by an employee driven improvement work which was visualized on improvement boards. The most important tool was Value stream mapping, since it was used to catalyze the improvement work. However, principles such as Just-in-time with constant takt times and cycle times were not possible to apply, due to the complexity of the process.

\subsubsection{Main conclusions}

There is a risk that quality development of a social service organization that is strongly focused on Lean practices implies a shift toward a technical quality dimensions (Grönroos, 1984) and what is measurable and tangible, such as process time and lead time. This may lead to reduced waste in the processes but there is a risk that the strong focus on efficiency will lead to impaired customer treatment if the functional quality aspects are overlooked. Therefore, this study shows that the meaning of value that is commonly used in Lean, which is inherited from industrial contexts, is rather limited in the public sector.

The study also suggests that there are possibilities to use Lean in social service, and that many operations can be improved to shorten lead times and reduce waste. Therefore, the Lean concepts include many tools and principles that are still useful in social service. However, it is difficult to quantify the outcomes since there are variances both in the income of work and available resources. 


\section{Discussion}

This chapter addresses the research questions based on the findings described in the appended papers.

\section{I RQI: How is Lean production used in practice?}

As noted in earlier research (Pettersen, 2009), it is difficult to generalize what is actually done under the Lean label, which is partly supported in the cases included in this thesis. Most of the literature states that Lean should be used broadly in all parts of the organization. However, the cases show that in practice, the work is concentrated to a few processes, mainly the operative processes. In manufacturing this means the processes that are directly related to the product in itself. In the public service, the Lean work are primarily related to the flow of patient, user or information. This limitation may also be a question of maturity. After reducing the most obvious waste in the core processes, the use of Lean gradually increases in other parts of the organization.

Although the literature suggests a set of tools associated with Lean, the actual practice in the cases shows that only a limited number of tools were used. This is in line with earlier research suggesting that shop-floor tools are only applicable in a manufacturing context (Hines et al., 2004). Consequently, Lean developed from a technical focus toward an organizational focus, in which the empowerment of the employees is a major aspect. Therefore, this study suggests that Lean in service and public sector contexts is more focus on the social aspects of Lean, rather than the technical aspects. This strengthen the relationship with total quality management, that can be defined by the four principles: focus on work processes; analysis of variability; management by fact; and learning and continuous improvement (Hackman and Wageman 1995). This stands in contrast to much of the research, which argues that most organizations focus too much on the tools (Radnor and Walley, 2008). In most of the cases, the decision-making and initiative in the improvement work were gradually transferred from management to employee teams. In addition, Lean is usually described by its principles, rather than tools and techniques.

In manufacturing, Lean implementation is often catalyzed by the use of a few specific tools and technologies. The Beta case used SMED and measurements 
of overall equipment efficiency, while Gamma used Kanban and 5S. The other organizations used improvement boards, 5S, and value stream mapping. Both $5 \mathrm{~S}$ and value stream mapping provide input to the improvement work since they can increase the understanding of the flow (VSM) and the structure of the workplace (5S), which then increase the possibility for a standardized work. Therefore, it is no surprise that they were used in an early stage of the Lean work in most of the cases.

This thesis aimed to specifically look at the public sector context. Questions 2 and 3 address this.

\subsection{RQ2: Which Lean principles, methods and tools are used in the public sector}

Previous research on Lean in the public sector shows that it must be adopted, rather than adapted into the context. In other words, it cannot be implemented in its purest form (Radnor, 2010a), but there are many ways to implement Lean in the public sector. The five Lean principles of Womack and Jones (1996) were used to discuss how Lean is implemented in the public sector.

\subsection{Define customer value}

Neither the concept of customer nor value is easily defined in the public sector. Both concepts must be discussed when Lean is used. As pointed out in earlier research, there are several kinds of customers within the public sector. Alford (2002) suggests that both clients and citizens can be regarded as customers. However, this thesis shows that the primarily customer in the public sector is the direct user of the service, whether it is a client, patient, or user. This is in line with the de Souza and Pidd's (20II) suggestion that the value flow should be seen from the user's perspective.

Despite the often mentioned aim to increase the customer value in organizations working with Lean, it can be discussed how and to what extent this is done in practice. In public sector, much of the work is performed in interaction with customer in front office processes. As shown in paper 3 , there is a lack of activities that are conducted in order to increase value in frontoffice processes. Instead, Lean is focused on improving the information flow in back-office processes. 


\subsection{Define Value flow}

The value stream mapping tool is commonly used in most every case organization to define and visualize the value flow, as suggested in the second principle of Womack and Jones (1996). This confirms the established picture that value stream mapping often is used as a starting point for the improvement work (Poksinska, 2010; Radnor and Walley, 2008). Two important drivers for the improvement work are associated with value stream mapping. First, activities that do not add value can be reduced. In several cases, the employees emphasized that Lean made them question which activities in the process were needed and which were not. Second, value stream mapping increases communication and exchange of experience, which were also seen in the cases. This emphasizes the importance of value stream mapping in the beginning of Lean implementations, as seen in earlier case studies. However, unlike manufacturing, the value stream mapping is not used as a starting point for achieving flow and pull. Instead, it is followed by an employee driven improvement work.

In manufacturing, the object in the value flow is the product that adds value (Bicheno, 2004; Hines et al., 1998). Since services often lack physical products, the users are the objects in the system. Seeing the service system from the user's view signifies a shift from the traditional way of optimizing the use of resources to optimize the flow, which is of the basis of Lean (Modig and Åhlström, 2012). This idea has become very important, especially within healthcare. Reducing the time needed for the total care process is a focus when the quality of the Swedish healthcare system is evaluated (Socialstyrelsen, 2013).

\subsection{Create flow}

There are many tools and methodologies that can be used to increase the flow. However, the definition of continuous flow differs between the public sector and manufacturing. Since the flow consists of information, rather than physical products, it is not visible in the same sense. This makes it more difficult to get an overview of the flow and improve it. The high variability also makes it impossible in most services to create a continuous, buffer-less flow. Nevertheless, it is possible to reduce the inventory between process steps and thereby reduce the lead time. As suggested in the introduction, this is an 
important aspect of Lean in the public sector. The cases in this study do not contradict that picture. This shows that the lead time is as important in a service context as in a manufacturing one, although neither takt time nor cycle time is used.

In general, the Lean tools supporting the management and planning of activities are used more than the tools supporting the production system. One of these tools is $5 \mathrm{~S}$, which is used as a way of structuring and improving the workplace. In organizations in which the physical artifacts are important, such as in healthcare, 5S is commonly used this way. However, in social service, the physical appearance of the workplace is less important, since it mostly creates information. The $5 \mathrm{~S}$ tool is not used in the same way as in manufacturing. Instead, it can structure information, both as electronic files and paper documents.

The principle of visual planning was also common in the case organizations, and more or less existed in all cases. In almost all social service groups, employees visualized their workload every week with a green, yellow, or red marker. This can be used to reschedule activities between employees. This represents one way of leveling the workload, which is a problem in many public organizations, since there are few possibilities to control the inflow of cases.

\subsection{Establish pull}

There are also tools and principles that are common in Lean but were not commonly used in the public-sector case organizations. Kanban was one of these tools. This highlights that Kanban is not a widely discussed concept in the public sector. This is in line with earlier research suggesting that there are few examples of Kanban in healthcare (Mazzocato et al., 2010). Kanban is one way of achieving pull (Ohno, 1988). As Åhlström (2004) suggests, the push-pull terminology generally lacks relevance in a service context, since the activities often cannot be performed without direct demand from the customer. Therefore, this thesis supports the general view that Kanban and pull are difficult to use in public-sector organizations (Poksinska, 2010).

\subsection{Strive for perfection}

The continuous improvement work is also an important part of Lean in public sector. This was carried out in different ways, although the most common was 
improvement boards and employee driven improvement work. These were tools for visualizing the progress of the improvement work, by which meetings were regularly held. At the meetings, the group discussed proposed improvement suggestions and made decisions on which suggestions to implement. In general, small groups were formalized to implement the improvement actions. An implication of this work is that the initiative for the improvement work was transferred from management to employees. However, there were some differences between the cases in how this work was performed and which role the manager took in this. A possible explanation is that the organization must achieve a higher level of maturity, meaning that the employees must have an overall perspective and take responsibility for the complete process. In some cases, this needed to be established within the frames of the Lean initiative. In other cases, the improvement work was ongoing for a long time. Therefore, the organization could build its Lean work on the earlier improvement work.

There was no radical change in the leadership in the case organizations. Go-togemba is one tool that already exists to a large extent, meaning that the manager spend time on the floor to better understand the value creation. In a public-service context, this does not necessarily mean going to a certain space and seeing the problem. Rather, it means making decisions based on the actual work in the organization. In the case of Eta, in general the support for improvement activities from managers was strong. In this sense, it is very important involve employees in the improvement work, since they are working closer to the user, and to anchor the decisions in the team. In both healthcare and the social services, leaders were generally recruited from within the organization, and they worked closely with the team. Therefore, go-to-gemba was, in many cases, a natural part of the leadership. 


\subsection{RQ3: What are the possibilities and limitations of using Lean in the public sector}

Table 6 shows an overview of the most important possibilities and limitations regarding Lean in the public sector.

Table 6: Possibilities and limitations

\section{Possibilities}

Employee empowerment

Flow orientation

\section{Limitations}

Limited view of quality

Lack of user focus

Limited use in front-office processes

\subsection{Possibilities}

There are two major possibilities with implementing Lean in public organizations. One concerns the role and responsibilities of employees and the other concerns process efficiency. Interestingly, these can be related to the two major ideas in the Toyota Way: Respect for People, and Continuous Improvement (Toyota Way, 200I).

\section{Employee empowerment}

Generally in public sector, there has been a lack of utilization of employees' creativity and knowledge (Ballé and Régnier, 2007). Paper 2 shows that Lean implementation may lead to new roles and responsibilities for the employees in healthcare organizations. The decision-making in healthcare is primarily done by highly skilled doctors, and employees from other groups are seldom encouraged to give their opinions, which limits knowledge contribution.

In Lean, teamwork is an important principle. Improvement work is usually performed in teams, in which every employee is encouraged to give their opinion. Moreover, the teams are often given responsibility for implementing the improvement, which facilitates employee-driven improvement work. This is an important aspect of the empowerment of employees, in terms of gaining control over the daily work (Conger and Kanungo, 1988). This represents a new view of what it means to be an employee in the public sector. This new 
role of employees began to develop in the 1990s, when the focus was on operational aspects (Joosten et al., 2009), which strengthens Hines et al.'s (2004) suggestion that Lean has evolved over the years. This might also be explained by the strong sociotechnical structure in Sweden, with a tradition of a relatively low degree of authority in leadership, and that the organizations already had more or less empowered employees. Another explanation would be that the organizations were more mature in their Lean work, so had the time to develop these aspects, although this would not explain some of the cases, which had only worked with Lean for a few years. However, empowering employees is very important, since the standardization of tasks potentially reduces choice autonomy (see Paper 2) and undermines some of the criticism against Lean from a working environment perspective (Hasle et al., 20I2).

\section{Flow orientation}

As Paper 2 states, one of the most frequent observations in the case organizations was that Lean was useful in improving the flow orientation. By mapping the value stream, the organizations could reduce waste, improve the structure, and to some extent, standardize the working procedures.

In particular, in the back-office processes (Zomerdijk and Vries, 2007), Lean increased the understanding of the work and how it could be improved. In the back-office processes, Lean is in general easier to use since the activities are more repeatable and predictable and the lower degree of service characteristics such as inseparability and perishability. In line with previous research, reducing lead time is a possible improvement that is addressed in many of the cases. However, it is often difficult to quantify the reduction since demand and resources vary over time (see Paper 3). There was a general feeling that the work was performed more efficiently, although the improvements were not as radical as in the manufacturing context, especially in comparison to Beta. It is also far away from Womack et al.'s (1990) claims that organizations working with Lean can reduce their lead time by 50 percent.

A prerequisite for flow orientation and process efficiency is basic stability, (Radnor and Walley, 2008). Earlier case studies suggest that this is an issue for healthcare organizations (Balle and Régnier, 2007). This is not surprising due to the traditional organization primarily in the healthcare public sector, which is 
characterized by functional silos with little cooperation between departments (Bahensky et al., 2005). Considering the difficulties with establishing a basic stability, this study suggests that the success stories described in the introduction represent a rather limited part of the healthcare organization, since only one or a few processes were described in most cases (Modig and Åhlström, 2012; Sonne, 2009). It takes time and effort to use Lean on a broader scale in healthcare. This also applies to social service, although the organization is less characterized by functional boundaries.

\subsubsection{Limitations}

There are three major limitations in this study. The first is the view of quality in public sector when using Lean. The second limitation concerns the limitation in user focus when public organizations are working with lean. The third is about the limited use of Lean in front office processes,

\section{Limited view of quality in the public sector}

In manufacturing, Lean focuses on technical quality, rather than functional quality, in terms of the emphasis on product quality and delivery precision. In other words, the right product in the right amount at the right time is the definition of Just-in-Time (Ohno, 1988). A problem for the public sector is that it is often difficult to make changes in service content, since it is financed by the government, so the level of social support or care is politically decided and defined by the law. This makes the functional quality very important for the quality experience in the public sector. There is a risk that the Lean initiative will narrowly focus on reducing lead time, which is one of few technical qualities that can be improved by the organization. This is exemplified by Modig and Åhlström's (2012) story presented in the thesis introduction, in which the breast cancer clinic built on Lean principles radically shortened the time for diagnosis. This is a rather limited focus from a service quality perspective. Therefore, there is a need to discuss how service quality in general, and in public services in particular, can be achieved. Technical quality dimensions certainly have a place in the public sector but, as Paper 3 shows, this is not enough to provide high-quality service to users. The functional quality dimension, or, how the service is provided, is very important for the overall service experience and the organization therefore needs to work with this dimension as well. 
The functional quality dimension is difficult to improve by using Lean tools and technologies, since the functional quality is often achieved in the interaction between customer and provider, and every situation is unique. Instead, the organization should strive for improving the aspects needed for increasing the functional quality. One obvious example of how the functional quality can be improved is time spent with user or patient. If the employees are stressed, it will be very difficult for them to achieve a high functional quality in the service. Therefore, to make the administrative work more efficient, time and resources can be made available to increse the functional quality.

\section{Lack of user focus}

Paper 3 shows a lack of user focus when Lean is used in the public sector. As mentioned, there are in the public sector several customers besides the user, which complicates how quality is seen and managed. When technical quality is delivered to the user, this is commonly a compromise between the needs of citizens of the society and the user. Therefore, it is not always possible to fulfill the user's needs. In addition, the criterion that an activity is value-adding if the customer is willing to pay for it (Ohno, 1988) is not fully transferable to the public sector since the user does not pay directly for the service.

Therefore, it is often difficult to increase value by adding features to the service. Instead, the organization is focusing on waste reduction, such as shortening of lead times, resource efficiency and consistent quality. This is a limitation in user focus. In order to increase the knowledge about the user's needs and expectations regarding the service, it is important to utilize user feedback as input to an improvement work

\section{Limited use in front-office processes}

Another limitation is that Lean is primarily used in back office processes, in the activities that are performed without direct contact with the user. As suggested in Paper 3, the main reason for this is that front-office processes imply a high degree of service characteristics such as inseparability and heterogeneity. This means that the variability in the process is high and that it is many times difficult to plan for how to fulfill the individual user's needs. This makes a detailed standardization of tasks difficult to use. Instead some unorthodox tools are used, primarily checklists, to ensure that the every step 
of the process is performed. This shows that the level of standardization is not as high as in highly repetitive manufacturing. Restricting the use of standardization is in line with Brandt and Stigendahl (20I2) and Seddon et al. (20II). Instead, the focus should be on increasing the flexibility in the process to increase the ability to absorb user-induced variations in demand.

The lack of standardization means that it is difficult to establish a basic stability, which is an important prerequisite for establish flow and pull in the process (Radnor and Walley, 2008). This means that public organizations have little opportunities of using Lean extensively in the front office processes.

However, this does not mean that standardization has no place at all in public service. It can and should be used in processes with little user involvement but also, to a limited extent, in processes where users are involved. The aim should be to reduce the variability that comes from internal mistakes and deviations from best practices. In that sense, the theory that Lean ideas can easily be transferred to service contexts is valid (Bowen and Youngdahl, 1998), although researchers supporting this theory tend to draw too far-reaching conclusions about the generality of Lean's production-line approach in a service context. The examples from fast-food are not representative of all service processes, especially not in the public sector, which are far more complex in terms of customer, quality and processes. This makes the argumentation from Modig and Åhlström (2012) and Lord (Sonne, 2009) insufficient as motivation for using Lean in public sector. Although Lean can lead to improvements in the technical quality dimension of the back office processes, this does not automatically lead to an improvement of the functional quality and in the front office processes. 


\section{Conclusion and contribution}

This thesis aims to increase understanding of how Lean production is used in practice by different organizations and what relevance it has for organizations' improvement, primarily in the public sector. The current state of research is rather limited, focusing on the implementation of one or a few tools or methods (Poksinska, 2010; Radnor and Walley, 2008) and does not consider Lean from a holistic perspective discussing both possibilities and limitations. This thesis is based on in-depth case studies of Lean implementations in healthcare and social service organizations to contribute to the knowledge about Lean as an improvement concept in the public sector.

\section{I Theoretical implications}

How Lean is used in practice?

This thesis has shown that Lean often has a narrow scope when it is used in practice, and that the use of tools and techniques are rather limited. Instead, most organizations focus on creating structures for improvement work and building organizational capabilities with the use of e.g. 5S, improvement teams and flow chart. Especially within public sector organizations, the use of tools for specific improvements, such as Just-In-Time, Heijunka and Poka-Yoke is quite limited. In this sense, the connection to other concepts for quality increases.

Which Lean principles, methods, and tools are used in the public sector and what are the possibilities and limitations?

A central theme in this thesis has been how Lean can be used to improve the quality in the public sector. In Table 7, a model for how to improve the technical and functional quality in public sector is presented. The model serves as a basis to present the most important conclusions and contributions of this thesis. 
Table 7: A model for improving quality in public service organizations

\begin{tabular}{|c|c|c|}
\hline & Front-office processes & Back office processes \\
\hline Functional quality & $\begin{array}{l}\text { Supporting employees' } \\
\text { possibilities to create value } \\
\text { with the users }\end{array}$ & $\begin{array}{l}\text { Employee-driven } \\
\text { improvement work, process } \\
\text { improvements using Lean } \\
\text { principles }\end{array}$ \\
\hline Technical quality & $\begin{array}{l}\text { Avoidance of deviations and } \\
\text { mistakes, reduce failure } \\
\text { demand }\end{array}$ & $\begin{array}{l}\text { Using Lean tools and } \\
\text { methodologies }\end{array}$ \\
\hline
\end{tabular}

The possibility to use Lean as it is defined in this thesis highly depends on the degree of service characteristics of the specific process. The front office processes imply an interaction with users and therefore contain a high degree of service characteristics. The back-office processes have usually a low degree of service characteristics and are more similar to processes in the manufacturing context. In order to improve the public sector, different practices should be used depending on the characteristics of the process. The most important aspect is that Lean, when applied in manufacturing, is primarily focused on increasing technical quality, while service organizations also needs to focus on functional quality to provide a good experience with the service.

In front office processes, the functional quality can be improved by supporting the individual employee's possibilities to provide the best possible service. Quality is mainly achieved by professional skills of the employee. For instance, doctors treating patients should be trusted to make their own decisions and work in their own way. This can be also used for social service, in which social workers know how to interact in situations with users. In such cases, the task of management is to support their development and decrease obstacles that hinder the possibility to provide create value. An important conclusion in this thesis is that Lean as improvement concept has a limited value to improve the functional quality in the front office processes.

To improve the technical quality in front-office processes, the main objective is to avoid mistakes and failures, which may create a failure demand. This is mainly done by setting standards and making checklists for the most common processes. In the case of the social service organization, checklists were made, ensuring that the right information were given and asked for. 
Lean practices for back-office are more similar to manufacturing. Thus, Lean tools and principles are more relevant to be applied in this context. To improve the functional quality a systematic, employee-driven improvement work can be initiated. In public organizations are employees often an unused potential for improvement. Empowerment and giving employees the main responsibility for the improvement work may therefore contribute to the improvement of public sector. By engaging the people that mainly interacts with the users, aspects considering the functional quality can be emphasized within the organization.

In order to reduce the waste in the process, several Lean tools can be used. Value stream mapping and $5 \mathrm{~S}$ were popular tools that were used at the case organizations. This supports experience from earlier studies of Lean in healthcare (Poksinska, 2010). Lean is used as a method for process improvement and lead time and waiting time reduction, which increases the technical quality. Hence the technical quality does not only consists of the actual content of the service but also the performance of the service system.

This thesis suggests that a Lean implementation in a public sector will primarily lead to the improvement of the technical quality, whereas it will have a little influence on the functional quality. This means that when Lean practices are used on a process, the focus will predominately be on internal efficiency and shortening lead times. There is a need for a discussion about how the functional quality can be improved in public organizations. Otherwise, there is a risk that the user's perspective is lost, and the focus on internal processes will make the user a passive receiver of services. Due to the current discourse in service research (e.g. Vargo and Lusch, 2004), where the customer is seen as an active participant of the service provision and the service is always provided in interaction between service provider and customer, this is a weakness.

By showing that Lean has a limited value for improving the functional quality, this study questions the general rhetoric in Lean literature that suggests Lean always increases the value for the user. The success stories that were presented in the introduction only address a limited part of quality in public sector organizations and there is a need for a broadened discussion about Lean in relation to quality in service. Much of the work in public sector is performed in interaction with the user, which underlines the importance of front office 
activities. Therefore, this thesis suggests that Lean should be supplemented with other improvement activities, with a focus on improvement of functional quality.

\subsection{Managerial implications}

This thesis shows that a common problem when Lean is used is that the underlying problems often are unclear. Organizations do not have a clear picture of why they are using Lean and what goals they should have to succeed. When the implementation is preceded by a thorough analysis of where the organization is and aims. Lean should not be used just because "everybody else does it". However, in organizations where they key characteristics of the change process (problem definition, goals, metrics, analysis and practices) are closely aligned, the tools, techniques and principles associated with Lean have shown to be useful.

This thesis shows that Lean undoubtedly can, to some extent, be used in contexts within the public sector. In every organization, there are possibilities for using Lean tools to make processes more efficient. For example, a standardized way of working will lead to a service that depends less on the individual service provider. This can also increase the value for users, since more resources can be allocated to the value-adding activities that are performed in the presence of users. However, if there is too much focus on the internal efficiency, there is a risk that the ability to meet the different user needs that is very important for the service context will be ignored.

The possibility to use Lean as it is defined in this thesis highly depends on the degree of service characteristics of the specific process. Therefore, it is very important to consider the characteristics of the process when working with Lean. In particular, the characteristic of heterogeneity of user needs seems to be a major difficulty when Lean is used in service processes, since the service provided need to be fitted with different users. In organizations with a high degree of service characteristics in processes, quality can be improved primarily by building a system that provides the employees the possibilities to adjust the service in line with individual user's needs. By doing that, the flexibility to meet individual user's needs and demands will increase which is a very important aspect of all service system. 


\section{References}

Ahlstrom, P., 2004. Lean service operations: translating lean production principles to service operations. Int. J. Serv. Technol. Manag. 5, 545-564.

Alford, J., 2002. Defining the client in the public sector: A social-exchange perspective. Public Adm. Rev. 62, 337-346.

Antoni, C., 1996. Lean production in Europe: a matter of technical adjustment or cultural change? Appl. Psychol. 45, I39-142.

Arlbjørn, J.S., Freytag, P.V., Haas, H. de, 20I I. Service supply chain management: A survey of lean application in the municipal sector. Int. J. Phys. Distrib. Logist. Manag. 4I, 277-295. doi: I0.1 108/0960003 I I | | 123796

Bagley, A., Lewis, E., 2008. Debate: Why Aren't We All Lean?

Bahensky, J.A., Roe, J., Bolton, R., 2005. Lean Sigma-Will It Work for Healthcare? J. Healthc. Inf. Manag. 19, 39.

Ballé, M., Régnier, A., 2007. Lean as a learning system in a hospital ward. Leadersh. Health Serv. 20, 33-4I.

Barraza, M.F.S., Smith, T., Dahlgaard-Park, S.M., 2009. Lean-<IT> kaizen</IT> public service: an empirical approach in Spanish local governments. TQM J. $21,143-167$.

Bateson, J.E., 1979. Why we need services marketing. Division of Research, Graduate School of Business Administration, Harvard University.

Benbasat, I., Goldstein, D.K., Mead, M., 1987. The case research strategy in studies of information systems. MIS Q. II.

Benders, J., Slomp, J., 2009. Struggling with solutions; a case study of using organisation concepts. Int. J. Prod. Res. 47, 5237-5243.

Bergman, B., Klefsjö, B., 20I0. Quality from customer needs to customer satisfaction. Studentlitteratur.

Bertholds, E., 20I0. Lean-marknaden passar inte i sjukvården. Läkartidningen |560-|56|.

Bevir, M., Rhodes, R.A., Weller, P., 2003. Traditions of governance: interpreting the changing role of the public sector. Public Adm. 8I, I-I7.

Bhasin, S., Burcher, P., 2006. Lean viewed as a philosophy. J. Manuf. Technol. Manag. 17, 56-72.

Bhatia, N., Drew, J., 2006. Applying lean production to the public sector. McKinsey Q. 3, 97-98. 
Bicheno, J., 2004. The new lean toolbox: towards fast, flexible flow. Picsie Books Buckingham.

Bowen, D.E., Youngdahl, W.E., 1998. “Lean” service: in defense of a production-line approach. Int. J. Serv. Ind. Manag. 9, 207-225. doi: I0.I I08/095642398|02235 I0

Boyne, G.A., 2002. Public and Private Management: What's the Difference? J. Manag. Stud. 39, 97-I22. doi: I0. I | I |/|467-6486.00284

Brandt, J., Stigendahl, L., 2012. Lean och systemsyn i stat och kommun.

Brännmark, M., 20I2. Lean i kommuner och myndigheter: En översikt över existerande empirisk forskningslitteratur.

Brown, S.W., Swartz, T.A., 1989. A Gap Analysis of Professional Service Quality. J. Mark. 53, 92-98. doi:I0.2307/I25।4I6

Bryman, A., Bell, E., 2003. Business research methods.

Chassin, M.R., Galvin, R.W., 1998. The urgent need to improve health care quality: Institute of Medicine National Roundtable on Health Care Quality. Jama 280, 1000-1005.

Cleary, P.D., McNeil, B.J., 1988. Patient satisfaction as an indicator of quality care. Inq. J. Med. Care Organ. Provis. Financ. 25, 25-36.

Conger, J.A., Kanungo, R.N., 1988. The empowerment process: Integrating theory and practice. Acad. Manage. Rev. 13, 47I-482.

Dahlgaard, J.J., Dahlgaard-Park, S.M., 2006. Lean production, six sigma quality, TQM and company culture. TQM Mag. I8, 263-28I. doi:I0.| |08/095447806/0659998

De Souza, L.B., Pidd, M., 20I I. Exploring the barriers to lean health care implementation. Public Money Manag. 31, 59-66.

Denhardt, R.B., Denhardt, J.V., 2000. The new public service: Serving rather than steering. Public Adm. Rev. 60, 549-559.

Drotz, E., Poksinska, B., 2014. Lean in healthcare from employees' perspectives. J. Health Organ. Manag. 28, I77-195. doi:I0.I I08/JHOM03-2013-0066

Eisenhardt, K.M., 1989. Building theories from case study research. Acad. Manage. Rev. 14, 532-550.

Elg, M., 200 I. Performance measures and managerial work: a modified behavior setting approach to the study of usage of performance measures in managerial meetings. Linköpings universitet. 
Emiliani, M.L., 2006. Origins of lean management in America: the role of Connecticut businesses. J. Manag. Hist. 12, 167-184.

Flyvbjerg, B., 2006. Five misunderstandings about case-study research. Qual. Inq. 12, 219-245.

Fountain, J.E., 200I. Paradoxes of public sector customer service. Governance 14, 55-73.

Gibbert, M., Ruigrok, W., Wicki, B., 2008. What passes as a rigorous case study? Strateg. Manag. J. 29, I465-1474.

Gold, R.L., 1958. Roles in sociological field observations. Soc. Forces 217-223.

Grönroos, C., 1984. A service quality model and its marketing implications. Eur. J. Mark. 18, 36-44.

Gummesson, E., 2003. Fallstudiebaserad forskning.

Hackman, J.R., Wageman, R., 1995. Total quality management: empirical, conceptual, and practical issues. Adm. Sci. Q. 309-342.

Hartley, J., 2004. Case study research. Essent. Guide Qual. Methods Organ. Res. 323-333.

Hasle, P., Bojesen, A., Jensen, P.L., Bramming, P., 20I2. Lean and the working environment: a review of the literature. Int. J. Oper. Prod. Manag. 32, 829-849.

Hines, P., Found, P., Griffiths, G., Harrison, R., 20I I. Staying Lean: thriving, not just surviving. CRC Press.

Hines, P., Holweg, M., Rich, N., 2004. Learning to evolve: a review of contemporary lean thinking. Int. J. Oper. Prod. Manag. 24, 994-10II.

Hines, P., Martins, A.L., Beale, J., 2008. Testing the Boundaries of Lean Thinking: Observations from the Legal Public Sector. Public Money Manag. 28, 35-40. doi:I0.1 I I I/j. I467-9302.2008.006/6.x

Hines, P., Rich, N., 1997. The seven value stream mapping tools. Int. J. Oper. Prod. Manag. 17, 46-64.

Hines, P., Rich, N., Bicheno, J., Brunt, D., Taylor, D., Butterworth, C., Sullivan, J., 1998. Value stream management. Int. J. Logist. Manag. 9, 25-42.

Högfelt, D., Sjögren, T., Weimarsson, H., 20I I. Lean Healthcare: Jakten på nya nyckeltal i den svenska sjukvården.

Holweg, M., 2007. The genealogy of lean production. J. Oper. Manag. 25, 420437. 
Jaaron, A., Backhouse, C., 20I0. Lean manufacturing in public services: prospects for value creation, in: Exploring Services Science. Springer, pp. 45-57.

Jansson, T., Sorpola, A., 2012. Lean-Produktion i skolan.

Joosten, T., Bongers, I., Janssen, R., 2009. Application of lean thinking to health care: issues and observations. Int. J. Qual. Health Care 2I, 34I-347.

Krafcik, J.F., 1988. Triumph of the lean production system. Sloan Manage. Rev. $30,4 I-52$.

Krings, D., Levine, D., Wall, T., 2006. The Use of" Lean” in Local Government. PUBLIC Manag.-LAWRENCE THEN Wash.- 88, 12.

Kvale, S., 2007. Doing interviews. Sage Publications, Incorporated.

Kvale, S., Brinkmann, S., 2009. Interviews: Learning the craft of qualitative research interviewing. Sage.

Landsbergis, P.A., Cahill, J., Schnall, P., 1999. The impact of lean production and related new systems of work organization on worker health. J. Occup. Health Psychol. 4, 108.

Lane, J.-E., 2000. The public sector: concepts, models and approaches. Sage.

Langstrand, J., 2012. Exploring organizational translation : A case study of changes toward Lean Production.

Levitt, T., 1972. Production-line approach to service. Harv. Bus. Rev. 50, 4I52.

Liker, J.K., 2004. The toyota way. Esensi.

Liker, J.K., Hoseus, M., 20I0. Human resource development in Toyota culture. Int. J. Hum. Resour. Dev. Manag. 10, 34-50.

Liker, J.K., Meier, D., 2006. The Toyota Way Fieldbook: A Practical Guide for Implementing Toyota's 4Ps; [companion to the International Bestseller“" The Toyota Way"]. McGraw-Hill.

Lillrank, P., 1995. The transfer of management innovations from Japan. Organ. Stud. 16, 97I-989.

Lovelock, C., 20II. Services Marketing, 7/e. Pearson Education India.

MacDuffie, J.P., 1995. Human resource bundles and manufacturing performance: Organizational logic and flexible production systems in the world auto industry. Ind. Labor Relat. Rev. 197-221.

Mazzocato, P., Savage, C., Brommels, M., Aronsson, H., Thor, J., 20I0. Lean thinking in healthcare: a realist review of the literature. Qual. Saf. Health Care 19, 376-382. doi:10.1 I36/qshc.2009.037986 
Merriam, S.B., 1998. Qualitative research and case study applications in education.

Modig, Åhlström, 20 I3. "Lean är lösningen, inte problemet" [WWW Document]. DagensMedicin.se. URL http://www.dagensmedicin.se/debatt/lean-ar-losningen-inte-problemet/ (accessed 4.17.14).

Modig, N., Åhlström, P., 20II. Vad är lean. En Guide Till Kundfokus Och Flödeseffektivitet Stockh.

Modig, N., Åhlström, P., 2012. This is Lean: Resolving the Efficiency Paradox. Rheologica Publishing.

Monden, Y., 1983. Toyota production system: practical approach to production management. Industrial Engineering and Management Press, Institute of Industrial Engineers Norcross, GA.

Ohno, T., 1988. Toyota production system: beyond large-scale production. Productivity press.

Orre, J., Kirsebom, H., 20II. Lean production - polisens nya filosofi? [WWW Document]. Polisen.se. URL http://www.svenskpolis.se/Artikelarkiv/Artiklar-20 I I/Juni-20 I I/Sa-funkarLean/ (accessed 4.10.14).

Osborne, S.P., Radnor, Z., Nasi, G., 2013. A new theory for public service management? Toward a (public) service-dominant approach. Am. Rev. Public Adm. 43, I35-158.

Parasuraman, A., Zeithaml, V.A., Berry, L.L., 1985. A Conceptual Model of Service Quality and Its Implications for Future Research. J. Mark. 49, 4I50. doi: $10.2307 /|25| 430$

Parker, R., Bradley, L., 2000. Organisational culture in the public sector: evidence from six organisations. Int. J. Public Sect. Manag. I3, I25-I4I.

Parker, S.K., 2003. Longitudinal effects of lean production on employee outcomes and the mediating role of work characteristics. J. Appl. Psychol. 88, 620.

Pedersen, E.R.G., Huniche, M., 20II. Determinants of lean success and failure in the Danish public sector: A negotiated order perspective. Int. J. Public Sect. Manag. 24, 403-420.

Pegels, C.C., 1984. The Toyota production system-lessons for American management. Int. J. Oper. Prod. Manag. 4, 3-II.

Pettersen, J., 2009. Defining lean production: some conceptual and practical issues. TQM J. 2I, 127-142. 
Poksinska, B., 2010. The current state of Lean implementation in health care: literature review. Qual. Manag. Healthc. 19, 319-329.

Poksinska, B., Swartling, D., Drotz, E., 20I3. The daily work of Lean leaderslessons from manufacturing and healthcare. Total Qual. Manag. Bus. Excell. I-I3.

Radnor, Z., 2010. Transferring lean into government. J. Manuf. Technol. Manag. $21,4 I I-428$.

Radnor, Z., Osborne, S.P., 2013. Lean: a failed theory for public services? Public Manag. Rev. 15, 265-287.

Radnor, Z., Walley, P., 2008. Learning to walk before we try to run: adapting lean for the public sector. Public Money Manag. 28, I3-20.

Radnor, Z., Walley, P., Stephens, A., Bucci, G., 2006. Evaluation of the lean approach to business management and its use in the public sector. Scottish Executive Edinburgh.

Radnor, Z.J., 2010. Review of business process improvement methodologies in public services. AIM Research.

Radnor, Z.J., Holweg, M., Waring, J., 2012. Lean in healthcare: The unfilled promise? Soc. Sci. Med. 74, 364-37I.

Schmenner, R.W., 1986. How can service businesses survive and prosper. Sloan Manage. Rev. 27, $21-32$.

Schonberger, R.J., 1982. Some observations on the advantages and implementation issues of just-in-time production systems. J. Oper. Manag. 3, I-II.

Schroer, B.J., Black, J.T., Zhang, S.X., 1985. Just-In-Time (JIT), with Kanban, manufacturing system simulation on a microcomputer. Simulation 45 , 62-70.

Seddon, J., Caulkin, S., 2007. Systems thinking, lean production and action learning. Action Learn. Res. Pract. 4, 9-24.

Seddon, J., O’Donovan, B., Zokaei, K., 20I I. Rethinking Lean Service, in: Macintyre, M., Parry, G., Angelis, J. (Eds.), Service Design and Delivery, Service Science: Research and Innovations in the Service Economy. Springer US, pp. 4l-60.

Shah, R., Ward, P.T., 2007. Defining and developing measures of lean production. J. Oper. Manag. 25, 785-805. doi:I0.1016/j.jom.2007.01.019

Shah, S.G.S., Robinson, I., 2008. Medical device technologies: who is the user? Int. J. Healthc. Technol. Manag. 9, I8I-197. 
Shingo, S., Dillon, A.P., 1989. A study of the Toyota production system from an industrial engineering viewpoint. Productivity Press.

Silvestro, R., Fitzgerald, L., Johnston, R., Voss, C., 1992. Towards a Classification of Service Processes. Int. J. Serv. Ind. Manag. 3, 62-75. doi: 10.1108/09564239210015175

Socialstyrelsen, 20I3. Patientens väg genom vården - system för uppföljning av väntetider $\mathrm{i}$ vården - Rapport december 2013 [WWW Document]. URL http://www.socialstyrelsen.se/publikationer20 I3/20I3-12-20 (accessed 8.9.14).

Sonne, L., 2009. Vården har mer än industrin att tjäna på Lean. Intell. Logist. 2009, 6-8.

Souza, L.B. de, 2009. Trends and approaches in lean healthcare. Leadersh. Health Serv. 22, I2I-139. doi:10.1 108/1751 I870910953788

Spear, S.J., 2005. Fixing health care from the inside, today. Harv. Bus. Rev. 83, 78.

Suárez-Barraza, M.F., Ramis-Pujol, J., 20I0. Implementation of Lean-Kaizen in the human resource service process: A case study in a Mexican public service organisation. J. Manuf. Technol. Manag. 2I, 388-4I0.

Sugimori, Y., Kusunoki, K., Cho, F., Uchikawa, S., 1977. Toyota production system and kanban system materialization of just-in-time and respectfor-human system. Int. J. Prod. Res. 15, 553-564.

Toyota Way 200I [WWW Document], 20I4. URL http://www.toyotaglobal.com/company/history_of_toyota/75years/data/conditions/philosop hy/toyotaway200I.html (accessed 8.14.14).

Treville, S. de, Antonakis, J., 2006. Could lean production job design be intrinsically motivating? Contextual, configurational, and levels-of-analysis issues. J. Oper. Manag. 24, 99-123. doi:I0.1016/j.jom.2005.04.00 I

Vargo, S.L., Lusch, R.F., 2004. The four service marketing myths remnants of a goods-based, manufacturing model. J. Serv. Res. 6, 324-335.

Womack, J.P., Jones, D.T., 1996. Lean thinking: Banish waste and create wealth in your organisation. Rawson Assoc. N. Y.

Womack, J.P., Jones, D.T., Roos, D., 1990. The machine that changed the world. N. Y. Rawson Assoc.

Woodruff, R.B., 1997. Customer value: the next source for competitive advantage. J. Acad. Mark. Sci. 25, I39-I53.

Yin, R.K., 2009. Case study research: Design and methods. sage. 
62 References

Zaremba, M., 20I3. Patientens pris: ett reportage om den svenska sjukvaarden och marknaden. Weyler.

Zbaracki, M.J., 1998. The rhetoric and reality of total quality management. Adm. Sci. Q. 602-636.

Zeithaml, V.A., 198I. How consumer evaluation processes differ between goods and services. Mark. Serv. 9, 25-32.

Zomerdijk, L.G., Vries, J. de, 2007. Structuring front office and back office work in service delivery systems: An empirical study of three design decisions. Int. J. Oper. Prod. Manag. 27, 108-131. doi: I0.1 I08/0|4435707|07|4565 


\section{Appended Papers}

The articles associated with this thesis have been removed for copyright reasons. For more details about these see:

http://urn.kb.se/resolve?urn=urn:nbn:se:liu:diva- 110660 